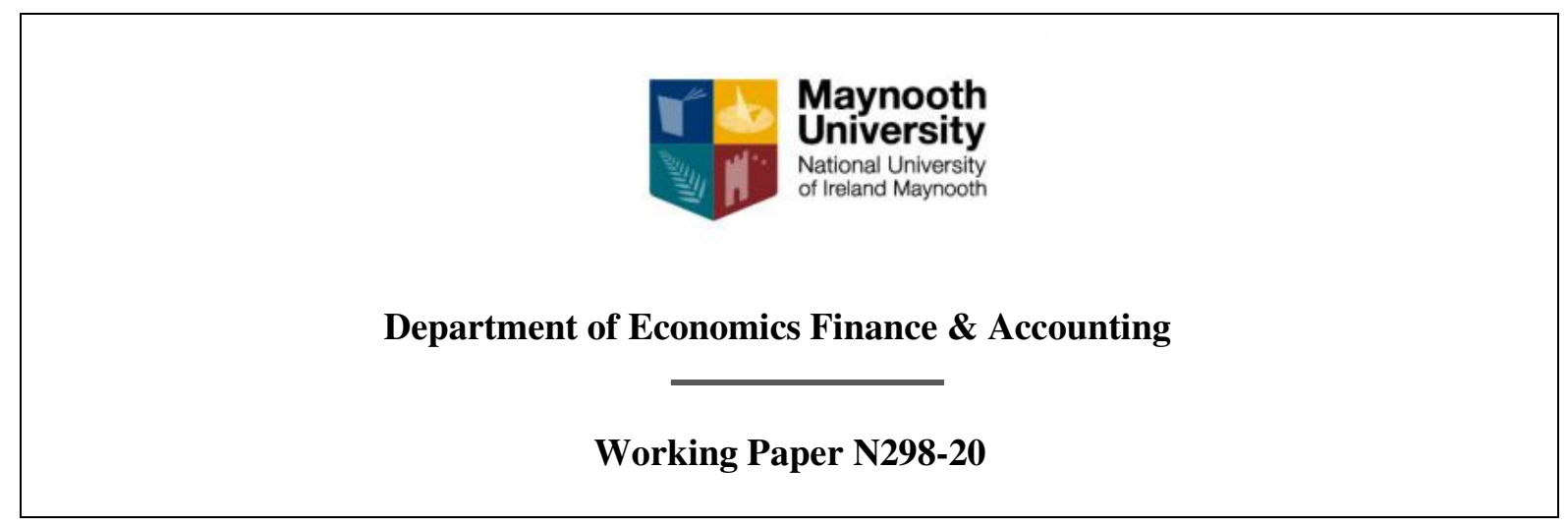

\title{
Industrial firms and systemic risk
}

\begin{tabular}{|c|c|}
\hline Mardi Dungey & Thomas Flavin \\
Tasmanian School of Business and Economics, & $\begin{array}{c}\text { Thomartment of Economics, Finance and Accounting } \\
\text { University of Tasmania, } \\
\text { Hobart, } \\
\text { TAS 7001, } \\
\text { Australia. }\end{array}$ \\
$\begin{array}{c}\text { National University of Ireland Maynooth, } \\
\text { Maynooth, }\end{array}$ \\
Co. Kildare, \\
Ireland.
\end{tabular}

\begin{abstract}
We investigate the systemic importance of U.S. industrial firms and analyse the firm-specific characteristics that identify systemically important industrials. We compute two firm-specific measures of systemic risk for 367 non-financial corporations and confirm that industrial firms are both vulnerable to systemic shocks and contribute to system-wide risk. Systemic risk measures exhibit substantial variation across firms and over time. Debt and trade credit are related to both dimensions of systemic risk, while a range of other firm characteristics are associated with systemic risk in at least one direction. The differences between the dimensions of risk and their associated characteristics underline the importance of analysing both measures of risk. Finally, we report some striking differences vis-à-vis the extant literature on banks and non-bank financials.
\end{abstract}

Keywords: Systemic risk; MES; $\triangle \mathrm{CoVaR}$; industrial firms; financial crises.

JEL Classification: G32. 
1. Introduction

Systemic risk and the systemic importance of financial institutions was propelled to the forefront of financial research and debate by the global financial crisis of 2007-09 and later by the Eurozone sovereign debt crisis. Bank failures across many developed countries and the impairment of debt and asset-backed securities markets brought the issue of systemic risk, its measurement and how to combat its threat to global attention. Given that the crisis which precipitated the turmoil originated within the banking sector and associated credit derivative markets (see Brunnermeier, 2009; Gorton, 2009 among others), much of the research on systemic risk has focussed on the banking and other nonbanking financial institutions. Some papers, e.g. Billio et al. (2012) and Drehmann and Tarashev (2013), take a narrow view of the system and limit their focus to the financial sector. However, it is argued by Acharya, Engle and Richardson (2012) that any definition of systemic risk must incorporate the real economy effects of such a shock. They also stress the importance of the connectedness of the system in measuring systemic risk. Even if firms are individually in good financial health, pervasive linkages across the industry can potentially propagate adverse shocks throughout the system, resulting in widespread disruption and possibly a systemic crisis. Even though non-financial corporations (NFCs) are not strictly part of the financial system, they are inextricably linked to financial institutions through their financing and investment activities. Furthermore, NFCs have important intra-industry linkages through trade credit, supply and production chains, making it difficult to diversify financial exposure to these industrial firms. Therefore, our goal is to assess the systemic importance of NFCs, both in terms of their contribution to this risk and their vulnerability to it. For a sample of S\&P 500 listed industrial firms, we compute two measures of systemic risk and relate these to a wide range of firm-level characteristics in an effort to paint a picture of what a systemically important industrial firm looks like.

There are many reasons to believe that adverse shocks experienced by these industrial firms will have repercussions for the financial system and the wider real economy, thus making such firms potentially systemically important. Firstly, in a report on global financial stability, the International Monetary Fund (2019) warn of the imminent threat to the financial system and global economy from 'corporate debt vulnerability'. With corporate indebtedness at record levels, they warn that a shock of half the magnitude of the most recent crisis, would leave about 40\% (approximately $\$ 19$ trillion) of corporate debt at risk across the seven largest economies. This growth in debt financing has been largely due to the low cost of debt and has been accompanied by a declining quality of debt to exacerbate the economic threat. Celik, Demirtas and Isaksson (2020) estimate that a quarter of all corporate bond issued in 2019 were non-investment grade, with only about $30 \%$ being rated A or higher. Secondly, from the financial contagion literature, we know that NFCs can play a key role in the transmission of shocks. Using a theoretical model, Korinek, Roitman and Vegh (2010) shows how a shock originating in the banking sector can lead to contagion between two NFCs, which were previously unrelated, accentuating the negative effect of the original disturbance. Likewise, network models, such as 
Acemoglu, Ozdaglar and Tahbaz-Salehi (2015), show large (either in magnitude or in number) shocks to NFCs can cause fragility in the financial system. Thirdly, empirical evidence that NFCs can propagate an adverse shock to other sectors is provided by Dungey and Gajurel (2014), Akhtaruzzaman and Shamsuddin (2016), and Dungey, Flavin and Lagoa-Varela (2020) among others, with strong evidence of bi-directional contagion between the financial and non-financial sectors, in both the U.S. and Eurozone markets.

Measuring systemic risk is a major challenge. The complex nature and dimensionality of systems would suggest that measures of systemic risk require huge volumes of data from the constituent entities of the system and technologies capable of tracking a myriad of bilateral relationships. In this sense, the tedious and painstaking stress tests of financial institutions are likely to produce the most accurate assessment. The downside of this approach is that they are time consuming and repeated infrequently at relatively long horizons. An alternative approach is to use market price data to extract systemic risk measures that are timely and relatively easy to compute. The marginal expected shortfall (MES) of Acharya et al. (2017), the SRISK of Brownlees and Engle (2017), the Delta CoVaR $(\triangle \mathrm{CoVaR})$ of Adrian and Brunnermeier (2016) and the Granger-causality approach of Billio et al. (2012) can all be computed from equity prices. ${ }^{1}$ Hence these systemic risk measures can be calculated rapidly and updated regularly for any stock market-listed firm.

Using variants of these measures, a voluminous literature has emerged on the systemic importance of financial institutions and the characteristics associated with highly systemic financials. The real-time detection of institutions that are either a threat to, or under threat from, the system is important for regulators posed with dealing with crises but equally, identifying the firm-level characteristics of these firms is crucial in forming policy to build resilience in the financial system. Likewise investors can use this information to design investment strategies to hedge against market downturns. Firm size (usually measured as market capitalisation or total assets) is the predominant characteristic associated with systemic risk among financial institutions. A large number of studies reach this consensus (see Tarashev, Borio and Tsatsaronis, 2010; Pais and Stork, 2013; Laeven, Ratnovski and Tong, 2016; and Varotto and Zhao, 2018 among others), with most attributing this relationship to the 'too-big-to-fail' theory, which expects large financial institutions to be 'bailed out' by government rather than allowing them to fail, as it would be too damaging for the system as a whole. Interestingly, firm size has little effect on the risk of individual banks but is important at the system level. Other key determinants of systemic risk for banks is the level of undercapitalisation (Laeven, Ratnovski and Tong, 2016), leverage and market-to-book value (Calluzzo and Dong, 2015), the level

\footnotetext{
${ }^{1}$ Other measures rely on CDS data, e.g. Huang, Zhou and Zhu (2009), Giglio (2011) and Nijskens and Wagner (2011); interbank market data as in Giratis et al. (2016) and Langfield, Liu and Ota (2014); and bond data as in De Sola Perea et al. (2019). For a comprehensive review of systemic risk measures, the reader is referred to Bisias et al. (2012).
} 
of interconnectedness with the rest of the financial system (Bostandzic and Weiß,2018) and corporate governance (Iqbal, Strobl and Vahamaa, 2015; Andries and Nistor, 2016; and Anginer et al., 2018). Interestingly, better governed firms are generally found to be more systemically risky due to engaging in higher risk activities, again with the expectation of being bailed out if these strategies go wrong.

Despite the sizable literature on financial institutions, relatively few studies have focussed on the systemic risk of non-financial institutions. There are some notable exceptions. Anginer et al. (2018) use a sample of U.S. NFCs as a benchmark against which to compare financial institutions and show that these NFCs are systemically risky. Similarly, Dungey, Luciani and Veredas (2018) develop an index of systemic importance and show that non-financial firms are consistently among the most systemically important firms, but they stop short of analysing the characteristics of high systemic risk firms. Outside of the U.S., Poledna, Hinteregger and Thurner (2018) analyse a large network of Austrian firms and conclude that NFCs are systemically important. They can attribute only $29 \%$ of total systemic risk to interbank linkages with the remainder emanating from bank-NFC and inter-NFC relationships. Van Cauwenberge et al. (2019) compute $\Delta \mathrm{CoVaR}$ for both financial and non-financial Dutch companies and find that NFCs rank among the most systemic firms. They relate their measure of systemic contribution to firm-level characteristics, and find that size, leverage, idiosyncratic risk and the degree of internationalisation are important for Dutch firms.

To the best of our knowledge, this is the first study to focus on U.S. industrial firms. We undertake a more extensive analysis of systemic risk by focusing on the bidirectional transmission of shocks between individual firms and the system and analyse the relationship between this risk and a broad range of firm characteristics. To address this issue, we analyse a sample of 367 non-financial S\&P 500-listed firms over the period 2005-2011. We compute two systemic risk measures, MES and $\triangle \mathrm{CoVaR}$ - discussed in greater detail in the next section - to measure distinct dimensions of system risk. These measures differ in the direction of causality. MES captures the vulnerability of the individual firm to a system-wide shock, while $\Delta \mathrm{CoVaR}$ estimates the effects of a firm-specific shock on the wider system. ${ }^{2}$ We then regress these systemic risk measures on a wide range of firm- and industry-level variables (which are discussed in section 3). In our empirical specification, we exploit variation in risk between- and within-firms and estimate a series of 'random effects within between' (REWB) regressions (see Bell and Jones, 2015). In REWB regressions, the cross-sectional (between) and longitudinal (within) relationship between each firm characteristic and systemic risk are estimated simultaneously and we report two coefficient estimates for each characteristic; one which allows us to characterize differences between systemically important firms, and a second, the within-effects, which allows us to determine what causes these firms to be systemically important.

\footnotetext{
${ }^{2}$ Adrian and Brunnermeier (2016) show that the causality of their $\Delta \mathrm{CoVaR}$ measure can be reversed to capture the effect of a systemic shock on individual firms.
} 
Our results reveal a number of interesting findings. Firstly, we confirm that industrial firms are systemically important with substantial and persistent MES and $\triangle \mathrm{CoVaR}$ measures. In general, they are dominated by corresponding measures for financials but are more persistent, especially for vulnerability to a systemic shock. Furthermore, both measures exhibit large variation across firms and over time. Secondly, distinguishing between systemic vulnerability and systemic contribution is important as we find a great deal of heterogeneity in the measures. Firms who rank highly in one risk dimension do not necessarily rank highly in the other. Hence focusing on the transmission of systemic risk in just one direction would miss vital aspects of the phenomenon and lead to inefficient policy formulation. Thirdly, the variables that are related to NFC systemic risk are quite different from those identified in the literature as driving systemic risk among banks and other non-banking financial institutions, reinforcing the need for our analysis. For example, firm size and corporate governance only appear to be associated with systemic contribution and not vulnerability. Fourthly, we find strong empirical evidence to reinforce the warnings of the International Monetary Fund (2019) report regarding the systemic importance of corporate debt. Financial debt is a significantly related to both systemic vulnerability and systemic contribution; the former is increasing in debt for all firms, while the latter exhibits such a relationship for large firms. The influence of debt is compounded by the importance of trade credit in determining systemic risk. This shows that firm linkages that are external to the financial system can also generate systemic risk and have the potential to impact on the wider economy. Interestingly, irrespective of the direction of shock transmission, firms who provide credit are always of higher systemic importance. Fifthly, the remaining characteristics of firms with high systemic vulnerability are very different from those of firms who contribute to systemic risk. This underlines the need for analysing systemic risk across both dimensions. Similarly, the factors that explain between- and within-firm variation are largely different.

The remainder of this paper is structured as follows. Section 2 details the employed measures of systemic risk, describes their computation and presents these measures for our sample of nonfinancial firms. Section 3 lists, and provides motivation for, the firm-specific characteristics that we include in our regression analysis of the driving forces associated with systemic risk. It then proceeds to present some preliminary univariate statistics before outlining our econometric methodology. Section 4 discusses our results, while Section 5 contains our concluding remarks.

\section{Measures of systemic risk}

The need for up-to-date information on systemic risk has led researchers to develop systemic measures based on publicly-available information, with their timeliness appealing to both policymakers and investors who need to react to unfolding events to minimise the negative repercussions associated with systemic episodes. These measures have predominantly been introduced in the literature on banks and financial institutions but are now being extended to NFCs (see Anginer et al., 2018; Van Cauwenberge et al., 2019). This is the approach that we adopt here. We compute two of the most popular 
measures; the marginal expected shortfall (MES) of Acharya et al. (2012) and Adrian and Brunnermeier's (2016) $\Delta \mathrm{CoVaR} .{ }^{3}$ We briefly review these measures and describe their computation before presenting the results for our sample of 367 S\&P-listed companies over our sample period, 20052011.

\subsection{Marginal Expected Shortfall (MES)}

Acharya et al. (2017) define MES as the marginal contribution of firm $j$ to the expected shortfall of the financial system, termed the market portfolio. It is designed to capture the vulnerability of firm $j$ to a system-wide shock. It can be readily and easily computed from a firm's publicly available share price. Specifically, the MES of firm $j$ is the expected value of its share-price return, conditional upon the market portfolio return being at or below the sample $p$-percentile over the estimated trading period $t$ (see Guntay and Kupiec, 2016). Hence, for a given estimation window, the MES of firm $j$, is given as:

$$
\operatorname{MES}\left(R_{j t}, p\right)=E\left(R_{j t} \mid R_{m t} \leq \operatorname{VaR}\left(R_{m t}, p\right)\right)
$$

where VaR denotes the market's value-at-risk with $\mathrm{p}$ set, in our estimation, to 5\%. The daily $95 \% \mathrm{VaR}$ for a given market portfolio is approximated by daily losses of $2 \%$ or worse. We choose the S\&P500 index as our market portfolio as it closely reflects the performance of the real economy. An institution's MES thus provides an estimate of the scale of losses a firm may experience during generally turbulent periods or subsequent to a large market disturbance. We calculate MES on a daily basis from 20052011. Following Anginer et al. (2018), we then compute an annual average of the measure to use in our analysis of the firm-level characteristics determine this dimension of systemic risk. In our analysis, we use the negative of MES so that firm-level systemic vulnerability is increasing in MES.

\subsection{Delta CoVaR}

We estimate a firm's $\Delta \mathrm{CoVaR}$ (Adrian and Brunnermeier, 2016) to capture the systemic contribution of each firm, i.e. the transmission of a firm-specific shock to the overall system. $\Delta \mathrm{CoVaR}$ captures the systemic impact of a firm's distress upon the financial system by estimating the change in the financial system's value-at-risk (VaR, with $\mathrm{x} \%$ certainty) that takes place conditional upon a tail event for firm $j$. For consistency with our MES variable, we set $\mathrm{x}$ equal to $95 \%$ in this analysis and check of the robustness of our results at the more stringent $99 \%$ threshold.

$\Delta \mathrm{CoVaR}$ relies on two conditional VaR estimates (CoVaR) (see Jorion, 2007). The financial system's CoVaR when firm $\mathrm{j}$ experiences a tail event, is defined as follows:

$$
\operatorname{Pr}\left(R_{f s} \leq \operatorname{VaR}\left(R_{f s} \mid j, q\right) \mid R_{j} \leq \operatorname{VaR}\left(R_{j}, q\right)=q\right.
$$

\footnotetext{
${ }^{3}$ The SRISK measure of Brownlees and Engle (2017) is similar to the MES and often used in the banking literature. Since it incorporates a capital requirement ratio, we exclude it from our analysis of NFCs.
} 
Here $\mathrm{R}_{\mathrm{fs}}$ represents the return of the financial system (e.g. a growth rate in a broad market index) and $\mathrm{R}_{\mathrm{j}}$ the return for firm $\mathrm{j}$, with q typically set to a low figure, e.g. $5 \%$. Note, firm $j$ 's returns are at, or have breached, its own 5\% VaR, meaning it has experienced a (left) tail event, resulting in historically large losses. Repeating the estimation, but conditioning upon the firm's 50\% VaR we estimate the firm's $\Delta \mathrm{CoVaR}$ as follows:

$$
\Delta \operatorname{CoVaR}\left(R_{f s} \mid j, 5 \%\right)=\operatorname{CoVaR}\left(R_{f s} \mid j, 5 \%\right)-\operatorname{CoVaR}\left(R_{f s} \mid j, 50 \%\right)
$$

Thus, Eq. (3) gauges the change in the value-at-risk of the financial system when firm $j$ goes from experiencing normal (median) returns to distressed returns. As proposed by Adrian and Brunnermeier (2016), we rely on quantile regression techniques to estimate this equation. This approach requires the inclusion of a number of state variables, from which the time variation in the $\Delta \mathrm{CoVaR}$ measure is generated. We include the change in the 3-month Treasury bill rate, term premium, the TED spread (which is often used to capture market liquidity), the credit spread and equity market volatility (VIX) in our specification. As with MES, we use the negative of $\triangle \mathrm{CoVaR}$ to that larger $\Delta \mathrm{CoVaR}$ implies a higher contribution to systemic risk.

\subsection{Systemic importance of U.S. industrial firms}

As a first step in our analysis, we compute and analyse the MES and $\triangle \mathrm{CoVaR}$ measures for each of the 367 industrial firms in our sample over the period 2005-2011. Each firm can be allocated to one of ten non-financial sectors according to the Fama-French industrial groupings and some of our results are presented by industry to facilitate a clearer exposition. For each firm, we compute our measures of systemic risk using its daily closing share prices. Table 1 presents some summary statistics. MES has a higher mean and standard deviation than $\triangle \mathrm{CoVaR}$. It is noteworthy that the standard deviation of values within a firm is much larger than the average values across firms. This is important in light of the estimation technique used (and discussed) below.

Figure 1 (top panel) plots the average MES and $\triangle \mathrm{CoVaR}$ of all NFCs for each year of our sample. The corresponding figures for an index of U.S. financials is included as a benchmark. An interesting pattern emerges. In general, financials score higher than NFCs in both dimensions of systemic risk but the systemic vulnerability and contribution to systemic risk is still significant across industrial firms. In the early years of our sample, 2005-06, both measures are relatively low implying that systemic risk is not a major threat to individual firms or to the broader economy. This changes quickly and significantly with the onset of the U.S. financial crisis in 2007.

Starting from mid-2006, MES climbs quickly and steeply, particularly for the financial sector. MES peaks for industrials in 2008 but continues to grow for financials, albeit at a decreasing rate until mid-2009. Thereafter it declines sharply, in contrast to the MES for NFCs which displays considerable persistence. This suggests that resolution programmes introduced to rescue banks and build resilience in the financial sector enjoyed some success. However, many of these policies initiated by government, 
though aimed at alleviating distress in the financial sector, often had an implicit assumption that a fully functioning financial system would keep credit flowing to NFCs and thus protect them from the financial shock. Figure 1 indicates that this knock-on effect was not strong enough to insulate industrials from the crisis. The prolonged vulnerability of industrials may be due to the lack of any targeted rescue programmes for NFCs and further aggravated by a global economic downturn and poor consumer demand in international markets, and Europe in particular. In the final year of our sample, the MES of financials and NFCs begin to diverge once more as the former experienced renewed turbulence due to the emergence of the Eurozone sovereign debt crisis and U.S. banks' exposure to government debt instruments issued by the crisis-ridden Eurozone periphery countries.

Pre-crisis, $\triangle \mathrm{CoVaR}$ was relatively low but larger for NFCs than for the financial sector. Again, mid-2006 marks the start of an increase in this measure, though it was more gradual than the increase in MES. $\triangle \mathrm{CoVaR}$ peaks for NFCs in 2007 and subsequently declines, returning to 2006 levels by the end of our sample. The $\Delta \mathrm{CoVaR}$ measure for financials overtakes that of NFCs in 2007 and continues its upward trend until the third quarter of 2008 before gradually declining until the onset of the Eurozone crisis. Its peak coincides with the collapse of Lehmann Brothers and the introduction of TARP and related programmes aimed at strengthening the riskiest banks and decoupling these banks from the wider financial system. For both financials and NFCs, Figure 1 shows that there is the potential to transmit adverse shocks to the wider system and thus, this risk needs to be managed not only for banks and financial firms but also for industrials.

\section{[Insert Figure 1 about here]}

The bottom panel of Figure 1 presents a 'box and whisker' diagram with firms grouped by industry to gauge differences in cross-sectoral importance of systemic risk measures. Even though the focus of this paper is on industrial firms, we include financial firms as a benchmark to help us to put the systemic risk of NFCs into perspective. Panel A focuses on MES. As expected, given the 2007-08 crisis originated in the financial sector, the vulnerability of the financial sector is the largest of all sectors. It has the highest median value at 4.11 and displays the greatest variation in MES scores. However, the vulnerability of other sectors is not inconsequential. Across NFC sectors, median values lie between 1.8 and just under 4, with a large range of realized values for all industries. The manufacturing, consumer durables and energy sectors appear to be especially vulnerable to a systemic shock. The corresponding information for $\triangle \mathrm{CoVaR}$ is presented in Panel $\mathrm{B}$ and a similar story emerges. Again, our graph shows that financials dominate the transmission of risk to the wider system. Financial firms contribute more to systemic risk than industrials, but this dimension of systemic risk is still important across industrial sectors. The energy sector is again at the top of the list (according to median values). With relatively small median differences across sectors, each sector has the potential to more or less equally contribute to a system-wide disturbance. The distribution of values is more clustered 
than for MES and there are more outliers on the lower left tail of the distribution (captured by the lower limb of the box and whisker diagram).

Finally, we address the question if it is the same firms scoring highly in both systemic risk measures. Figure 2 shows a scatter plot of MES versus $\triangle \mathrm{CoVaR}$. If the ranking of firms is the same in both dimensions of risk, then we should see firms on or close to a 45-degree line. That is not the case. While, the relationship is positive, it is far from a 1:1. Table 2 lists the names of the top (most risky) and bottom (least risky) 10 industrial firms in terms of their average MES (left column) and $\triangle \mathrm{CoVaR}$ (right column) scores across the whole sample. Strikingly, there is just one firm, National Oilwell Varco, which appears in the top 10 of both risk measures, while no firm feature in the bottom (least risky) of MES and $\triangle \mathrm{CoVaR}$. Table 2 also shows the rank of each firm in our sample in terms of each risk measure. It confirms great variation between their MES and $\triangle \mathrm{CoVaR}$ measures. Therefore, the firms that are most vulnerable to a systemic crisis are not the same as those who contribute most to such an event. Consequently, it is crucial to analyse systemic risk across both dimensions as focusing on just one measure would overlook important information about risk and produce less effective policies to combat its spread.

[Insert Table 2 and Figure 2 about here]

A more detailed analysis of Figure 2 permits the classification of industrials in terms of systemic risk. Dividing the plot into four quadrants, we see that at one extreme (south-west quadrant), there are firms who score low in both risk measures. These firms are not systemically important, i.e. their shocks do not endanger the system and they show little vulnerability to system-wide shocks. At the other extreme (north-eastern quadrant), there are a group of firms who simultaneously show high vulnerability to a systemic shock and whose own shocks contribute to a broader downturn. These firms have the capacity to propagate shocks across the system, not alone through their own idiosyncratic shocks but by feedback effects with the wider financial system. Firms in the off-diagonal quadrants tend to be high in one dimension of systemic risk and low in the other. While either showing high vulnerability or high contribution to tumultuous episodes, there is little danger of bidirectional feedback effects aggravating the crisis.

\section{Data and econometric methodology}

Having established that non-financial U.S. firms are of systemic importance, we seek to identify the firm-level characteristics that contribute to this type of risk, following the extant literature on banking and other non-banking financial firms.

\subsection{Potential firm-specific drivers of systemic risk}

Without a guiding theory as to the factors that may potentially contribute to systemic risk, we identify a set of potentially important variables from the literature on individual risk and beta risk and 
use regression analysis to determine their importance to systemic risk. ${ }^{4}$ Benoit et al. (2013) describe MES and $\Delta \mathrm{CoVaR}$ as transformations of beta (or something similar to beta in the case of $\Delta \mathrm{CoVaR}$ ). MES is the product of a time-varying firm beta and the expected shortfall of the market return and is increasing in both. $\Delta \mathrm{CoVaR}$ for firm $i$ is proportional to its tail risk, where the proportionality coefficient is the linear projection coefficient of the market return on the firm return (i.e. $\Delta \operatorname{CoVaR} i t(\alpha)=$ $\left.\frac{\rho_{i t} \sigma_{m t}}{\sigma_{i t}} \operatorname{VaR}_{i t}(\alpha)\right)^{5}$

Table 1 lists and describes the variables used in the study. It also provides some summary statistics and the source of the data. In the remainder of this subsection, we provide a brief motivation on the choice of these variables. One of the most direct links between a NFC and the financial system is through its use of debt financing. Hamada (1972) showed that a firm's beta is increasing in its borrowing. More recently, the International Monetary Fund (2019) report focuses on the threat to global financial stability being posed by the level of corporate indebtedness across the largest economies. We try to capture this potential relationship by including a number of debt-related variables in our regression specifications. Specifically, we include the level of debt (total debt to market capitalisation), debt maturity (long-term debt to total debt) and a number of debt specialisation measures, such as debt concentration (a dummy variable which takes the value of unity if at least $90 \%$ of debt is provided by a single lender) and a Herfindahl-Hirschman index of debt type usage. Other dimensions of a firm's relationship with external markets are captured through external financial dependence (EFD) and a measure of financing constraints (due to Hadlock and Pierce, 2010). Trade credit may also be important as it captures linkages between non-banking borrowers and lenders. ${ }^{6}$ Corporate defaults may produce contagious effects through the type of balance-sheet contagion described by Kiyotaki and Moore (2002) and the type of default chain in Das et al. (2007). Trade credit linkages are captured through accounts payable, accounts receivable and net trade credit. It is often found that firms with a reliance on external capital and trade credit perform worse during financial crises (see Rajan and Zingales, 1998; Beck et al, 2004; Klingebiel et al., 2007; and Love et al., 2007).

Firm size is consistently found to be a significant determinant of systemic risk in the banking literature, even though it has little impact on individual bank risk (see Tarashev, Borio and Tsatsaronis, 2010; Pais and Stork, 2013; Laeven, Ratnovski and Tong, 2016; and Varotto and Zhao, 2018). ${ }^{7}$

\footnotetext{
${ }^{4}$ We bear in mind that studies on the drivers of systemic risk in banks have shown that some characteristics that are risk reducing at the firm level can have the opposite effect (or no effect) at the system-level (see for example, Wagner, 2010; Mayordomo, Rodriguez-Moreno and Peña, 2014, among others). Notwithstanding, factors that have been shown to influence firm-specific risk and its beta risk seems a reasonable starting point.

${ }^{5}$ Benoit et al. (2013) write $\Delta \mathrm{CoVaR}$ as $\frac{\rho_{i t} \sigma_{m t}}{\sigma_{i t}}\left[\operatorname{VaR}_{i t}(\alpha)-\operatorname{VaR} R_{i t}(0.5)\right]$ or $\frac{\rho_{i t} \sigma_{m t}}{\sigma_{i t}} \operatorname{VaR} R_{i t}(\alpha)$ if the marginal distribution of returns is symmetric around zero, which says that a firm's $\Delta \mathrm{CoVaR}$ is directly proportional to its VaR. Adrian and Brunnermeier (2016) show that the relationship between VaR (firm risk in isolation) and $\triangle \mathrm{CoVaR}$ (contribution to systemic risk) is weak.

${ }^{6}$ Demirguc-Kunt and Maksimovic (2001) documents the importance of trade credit financing for both small and large firms.

${ }^{7}$ Across all firms, Subrahmanyan and Thomadakis (1980) finds that beta is decreasing in firm size.
} 
However, it is often argued that the importance of size is related to the implicit expectation that large banks will not be allowed to fail by the regulating authorities. Without the tacit belief that such a rescue package will be provided to NFCs, it is an interesting empirical question as to whether or not size influences systemic risk in our sample of industrial firms. We include firm assets as an absolute measure of size and market share (firm sales to total industry sales) as a measure of importance within an industry, since Ferris et al. (1997) has shown that dominant firms in an industry are more important.

Corporate governance is another variable that has been shown to impact on the systemic risk of financial firms. Again, this is often related to the risk-taking behaviour of large shareholder-friendly banks but, nevertheless, we include it as a potential determinant of NFC systemic risk. Parigi (2017) finds a significant relationship between a firm's beta and its corporate governance. Our main variable is sourced from Aggarwal et al. (2011) but since it is only available up to 2008, we also explore the influence of corporate ownership structures on systemic risk. Ownership structures such as dual-class share structure and family firms are often found to be less shareholder friendly and this may impact on the firm's systemic vulnerability or contribution. We capture these effects through dummy variables which take the value of unity if that type of ownership structure applies to that firm.

The financial health of the firm and its ability to meet its short-term obligations also has the potential to impact upon the overall system. We use a range of variables to capture these effects; profitability, cash holdings, liquidity (current assets to current liabilities), dividend payer (binary dummy variable that equals unity if firm pays a dividend) profit volatility, growth opportunities (market to book value of assets) and asset tangibility (gross property, plant and equipment to assets). Previous literature has shown that profitability is inversely related to beta (Gahlon and Gentry, 1982), while profit volatility has the opposite effect (Chung, 1989; Schlueter and Sievers, 2014). Variables such as cash holdings, liquidity, dividends, and asset tangibility may provide a buffer against systemic risk.

The lifecycle stage of a firm may also be important in determining its vulnerability or contribution to systemic risk. We include two measures of lifecycle, firm age and a lifecycle classification based on the multiclass linear discriminant analysis (MLDA) of Faff et al. (2016). The latter approach allocates firms to one of four lifecycle stages; birth, growth, mature, and shakeout/decline. Chincarini et al. (2016) finds that early stage firms are most vulnerable to market risk (beta risk), while this fragility declines over time. In contrast, well-established, mature firms are expected to contribute most to systemic events.

The degree of international exposure has been shown to influence individual firm risk (Mitton, 2002) and the systemic contribution of Dutch firms (Van Cauwenberge et al., 2019). Diversification theory says global operations may insulate firms from purely domestic shocks. Alternatively, greater geographical scope may potentially expose firms to more shocks. Chander et al. (2009) lend support to the former view when they reveal that cross-listing firms (which typically have large global operations) 
outperformed non-cross-listing firms during currency crises in their home country. We include foreign sales and a cross-listing dummy variable to capture the effects of internationalisation on systemic risk.

Product market conditions have also been shown to be an important determinant of individual firm risk. Behrens et al. (2013) show that the producers of more differentiated products were affected less by the trade collapse, which occurred in Belgium between 2008 and 2009. We use two variables, product market fluidity (see Hoberg et al., 2014) and R\&D expenditure, as proxies for this phenomenon.

\subsection{Univariate analysis}

Table 3 presents a preliminary analysis of the data. In particular, we compare the average firm in the top (most risky) and bottom (least risky) systemic risk quartiles and look at differences in firmlevel characteristics for the two that may potentially explain the differences in systemic risk. For MES, there are a relatively small number of firms in the top quartile with a large mass of industrial firms in the bottom, while the numbers are equivalent in the corresponding measures of $\Delta \mathrm{CoVaR}$. For many of our explanatory variables, there is a large difference between the high- and low-risk firms. For example, the most vulnerable firms tend to be smaller, while the largest contributors to systemic risk tend to be larger. Higher debt levels appear to be associated with higher MES, though there is little difference in debt levels between the top and bottom quartiles of the $\Delta \mathrm{CoVaR}$ distribution. We check if the differences in the firm-level characteristics between high- and low-risk firms are statistically significant by running a series of linear probability models (LPM) where the dependent variable takes the value of unity if the firm belongs to the most systemically risky quartile and zero if it belongs to the least systemically risky quartile. Differences in MES appear to be associated with a relatively small set of firm-level characteristics. Most vulnerable firms tend to be smaller in both financial size (market capitalization) and market share, tend to have more cash holdings and tangible assets, and have less trade debt. In contrast, the univariate analysis identifies a larger set of characteristics that may be associated with firms who transmit risk to the system. High $\Delta \mathrm{CoVaR}$ firms are larger in terms of market capitalization and market share, extend more trade credit while availing of less themselves, may face greater financial constraints. In both systemic risk measures, this analysis reveals potentially important cross-sectoral differences.

\subsection{Econometric methodology}

The most common approach, in the extant literature, to estimating the relationship between systemic risk and firm-level characteristics has been to use fixed effects regression methods on a panel of data (e.g. Iqbal, Strobl and Vahamaa, 2015; Laeven, Ratnovski and Tong, 2016; Anginer et al., 2018; Bostandzic and Weiß, 2018, among others). However, this approach focuses exclusively on the "withineffect' (i.e. the longitudinal relationship) and removes any 'between-effects'. Consequently, these studies identify the dynamic drivers of systemic risk but are unable to identify the causes of long-term (or average) differences between firms. An alternative approach, used by Calluzzo and Dong (2015), 
is to estimate pooled OLS regressions but this approach implicitly assumes that the between- and withineffects are the same and where this is violated, the estimated coefficients are some weighted average of the two and are uninterpretable. Ideally, we would like to simultaneously estimate the between- and within-effects of our regressors on systemic risk and, therefore, identify the factors driving long-term differences between firms and short-term, dynamic differences within firms. Bell and Jones (2015) propose the REWB regression which allows us to do this. With REWB regressions, the cross-sectional and longitudinal relationships between systemic risk and each risk predictor are modelled simultaneously by including the risk predictors twice in the regression; first as demeaned terms $\left(x_{i t}-\overline{x_{i}}\right)$, and second, as firm-level means (of each time-varying variable), $\overline{x_{i}}$.

$$
y_{i t}=\beta_{0}+\beta_{1}\left(x_{i t}-\overline{x_{i}}\right)+\beta_{2} \overline{x_{i}}+\text { Year }_{t}+\text { Industry }_{j}+\left(u_{i}+e_{i t}\right),
$$

where $y$ represents either MES or $\triangle \mathrm{CoVaR} . \beta_{1}$ and $\beta_{2}$ capture the longitudinal (within-effect) and the cross-sectional (between-effect) effects on systemic risk, respectively. The REWB approach is very flexible and produces exactly the same estimate (and standard deviation) for $\beta_{1}$ (the within-effect), while retaining and utilising cross-sectional information. Furthermore, it also allows us to check if the two effects are equal (i.e. $\beta_{1}=\beta_{2}$ ) as implicitly assumed by pooled OLS. This restriction is rejected in all our specifications, so we adopt the REWB approach throughout our empirical analysis. ${ }^{8}$

\section{Discussion of Results}

The REWB regressions are estimated by GLS and our results are presented in Sections 4.1-4.3 and in Tables $4-8$. We begin by painting a broad picture of the characteristics that are associated with systemically important non-financial firms and then delve deeper to present a finer analysis of some key variables, either suggested by the extant literature or our own results, that require more explanation.

\subsection{Identifying characteristics of systemically risk firms}

We begin with an analysis of the MES systemic risk measure and seek to identify firm characteristics associated with vulnerability to a system-wide shock. Our results are presented in Table 4. Firstly, we focus on the determinants of differences between firms (columns 1 and 2) and find statistically significant evidence that the level of debt and cash holdings impact positively on MES, i.e. heighten the sensitivity of firms to an economy-wide adverse shock. On the other hand, firm age, higher market share, profitability and liquidity reduce MES and are associated with greater resilience to a systemic shock. None of the other variables exhibit a statistically significant relationship with MES.

The systemic importance of financial debt (column 2) provides supporting evidence for the IMF warning that corporate indebtedness represents a looming danger to the global economy. Firms who carry a larger debt burden are more vulnerable to a common economic shock. This is likely to be due

\footnotetext{
${ }^{8}$ Random effects estimation produces coefficients which are a complex weighted average of the within and between effects, which render the coefficients largely uninterpretable.
} 
to a combination of increased difficulty in servicing the debt and higher rollover risk if the debt matures within a crisis period. The current low interest rate environment and favorable tax treatment of debt make debt financing an attractive vehicle for many NFCs. However, with debt levels among US corporates reaching record levels, this result should serve as a warning to both borrowers and lenders as to the potential adverse consequences that this may inflict on the financial system and the wider economy. None of the other debt variables - debt maturity or trade credit - have a statistically significant association with differences in systemic risk between firms in this specification.

The positive relationship between MES and cash holdings may, at first, seem counter intuitive since higher cash reserves have traditionally been viewed as a buffer against a systemic shock. In contrast, however, Acharya, Davydenko and Strebulaev (2012) shows that the relationship between cash holdings and credit risk is consistently positive. They build a theoretical model to explain this phenomenon and provide empirical evidence consistent with its predictions. The model builds on the precautionary motive for holding cash whereby firms who are nearer to default accumulate cash in an effort to bolster their financial position. The probability of default may fall in the short-term but increases at longer-term horizons. Our result is consistent with this prediction. Firms with higher levels of cash are already close to (or in) financial distress and tend to be more vulnerable to a system-wide shock. The relationship between cash holdings and systemic risk may also be related to the type of negative spiral associated with funding liquidity during a crisis (see Brunnermeier and Pedersen, 2009), whereby the tendency of firms to accumulate cash in times of uncertainty (see Riddick and Whited, 2009) drains vital liquidity from the system, which in turns exacerbates problems in accessing debt financing for corporations during crises and thus impairs the functioning of the financial system.

The estimated negative coefficient on firm age suggests that younger firms are most vulnerable to a systemic shock. Typically, these firms are more reliant on intermediated debt financing and are thus more fragile in the face of a financial downturn. Older firms tend to have better access to alternative sources of finance or greater capacity to fund themselves internally. As expected, more profitable firms are less fragile to system-wide shocks as their ability to finance operations out of earnings act as an shield against the turmoil. Firms with more liquidity (higher current ratio) are likewise better insulated against the crisis. Finally, market share is similarly negatively related to MES, showing that the firm's size relative to its industry competitors is a more important determinant of its systemic vulnerability than absolute size. Thus, profitability, liquidity and market share are all associated with greater resilience in the face of a systemic shock and firms with strong performance in these characteristics are likely to represent good credit risks even during a systemic event.

Some of the statistically insignificant variables highlight noteworthy differences between NFCs and financial firms. For example, the insignificance of firm size is in contrast to results commonly found for the banking industry for which firm size is often found to be the single most important characteristic associated with systemic risk (see Tarashev et al., 2010; Pais and Stork, 2013, Laeven et al., 2016, and Anginer et al., 2018; among others). Many studies relate its importance to the market expectation that 
financial institutions will be saved if they are deemed 'too big to fail'. Without the expectation of government-backed resolution programs in the NFC sector, size doesn't appear to offer any protection against system-wide shocks. Likewise, neither corporate governance nor our ownership variables (which may be associated with governance) are statistically significant in our between-firm regression specifications. ${ }^{9}$ This is an interesting difference between our results and the extant literature on financial firms where, for example, both Iqbal, Strobl and Vahamaa (2015) and Anginer et al. (2018) report that better corporate governance is associated with higher levels of systemic risk. This is often attributed to higher risk taking among institutions whose goals are more aligned with shareholders and can be, again, related to the expectation that financial firms will not be allowed to fail. Once more, it appears that the absence of such an expectation among NFCs results in no significant relationship between corporate governance and MES for industrial firms.

There exists sizable intra-industry differences in risk exposure; firms in the consumer durables, energy, manufacturing and chemical sectors are most exposed to systemic risk, with the consumer durables sector being most vulnerable. Differences in MES between industries are large: for instance, the difference in MES between consumer durables and non-durables sectors firms is 2.226 or $93 \%$ of average MES. Our industry findings align with those of Behrens et al. (2013) which shows that producers of consumer durables, intermediates and capital goods in Belgium experienced much larger falls in exports between 2008 and 2009. In a similar vein, Engle and Wang (2011) find that trade in durables and other non-essential goods are more adversely affected by demand shocks.

The within-firm estimates (columns 3 and 4) show that there are relatively few firm characteristics associated with changes in a firm's MES over time. Only debt, liquidity, asset tangibility and product market fluidity are found to be statistically significant in these regressions. Consistent with results for between-firm differences, debt is positively related, and liquidity is negatively related to MES. Thus, over time, increasing debt and falling liquidity are associated with heightened vulnerability to systemic events. Product market fluidity and asset tangibility both exhibit positive association with MES over. This former implies that the more competition a firm faces in its product market, the more vulnerable it is to a systemic event. In a highly competitive market, a single firm can be relatively easily replaced. The positive sign on asset tangibility is at odds with the evidence on individual firm risk. At the firm level, higher levels of asset tangibility are usually considered to be risk reducing as physical assets can be liquidated if necessary or help to maintain debt capacity through the collateral they offer to secure loans (Kiyotaki and Moore, 1997). While this is true at the firm level, we find the opposite effect at the system level ${ }^{10}$, with greater levels of asset tangibility being associated with greater vulnerability to system risk. This is possibly due to the increased illiquidity of these asset types during

\footnotetext{
${ }^{9}$ For a reduced sample for which we have information on managerial entrenchment, we also use this as a proxy for corporate governance. Our results are unchanged and are available from the authors upon request. ${ }^{10}$ Wagner (2010) has already shown, for banks, that actions which may make the individual more resilient can have the opposite effect on the financial system.
} 
an economic downturn when firms may be forced to divest assets in periods of low demand. Deleveraging during a crisis results in large haircuts on asset values, producing downward price spirals or cascades (Shleifer and Vishny, 2011). Hence, holding tangible assets can increase systemic vulnerability despite reducing risk during normal time periods.

As well as being statistically significant, our between- and within-estimates are also economically significant. For instance, our between-firm analysis implies that a one standard deviation change in debt results in a difference in MES that ranges between 0.049 and 0.056 depending on the regression specification or approximately $2 \%$ of average MES. The economic significance of profitability, cash holdings and market share are even larger, with changes in these variables associated with large changes in systemic risk. Likewise, within-firm estimates produce similarly large economic effects. In this dimension, a one standard deviation change in debt produces movement in MES of between 0.09 and 0.13 (3.8\% to $5.5 \%$ of average MES). The economic impact of similar changes in profitability, cash holdings and market share are at least as great as, and often larger than, that of debt.

[Insert Table 4 about here]

We next turn to an analysis of $\Delta \mathrm{CoVaR}$, which captures the contribution of individual firms to systemic risk. Table 5 reports our results. The picture of the type of firm that emerges of an important source of systemic risk is very different from the type of firm that is vulnerable to a systemic crisis, which is consistent with the evidence of Table 2 and Figure 3. Compared to our MES analysis, a greater number of firm-level characteristics are statistically significantly associated with the $\Delta \mathrm{CoVaR}$ measure, especially when we focus on differences between firms. The contribution of industrial firms to systemic risk is positively related to size, both in the absolute sense (assets) and relative to competitors (market share). This result is in line with previous analysis of financial firms and shows that larger industrial firms contribute more to systemic episodes than smaller firms and is consistent with Ferris et al. (1997) which has shown that dominant firms are more important within an industry. This can be due to their individual size or the linkages they have with other parts of the system. As with MES, asset tangibility exerts a positive influence on $\Delta \mathrm{CoVaR}$. Again, this positive association shows that characteristics that make firms individually more resilient can have the opposite effect on the system as a whole. During a systemic event, physical assets are often illiquid and consequently, discounts may be suffered if assets need to be sold off. In the extreme case of asset fire sales, discounts are often substantial and through this mechanism, distressed firms appear to exacerbate market downturns by having relatively higher contributions to systemic crises, as well as being more vulnerable (as discussed earlier). We also find that dividend-paying firms are positively related to our measure of contribution to systemic risk. Though not contractually obliged to do so, it is generally accepted that firms are reluctant to cut dividends due to the adverse signal that it transmits to the investment community (Brav et al., 2005). ${ }^{11}$ Therefore, a

\footnotetext{
${ }^{11}$ John et al. (2015) places cash dividend payments at the top of a payout precommitment hierarchy, ahead of contractual debt obligations and other forms of cash distribution to stakeholders.
} 
greater number of dividend payers is likely to require a greater proportion of cash resources and thus reduce cash available for other system-wide activities. Furthermore, the IMF (2019) reports an increasing tendency for firms to fund dividend payouts by borrowing. Such dividends are unsustainable (without growth), implying that an economic downturn is likely to raise the systemic contribution of these firms.

Interestingly, a number of factors are associated with lower levels of systemic risk. Higher contributors to systemic risk appear to use less debt and use less trade credit (though in subsequent analysis, we show that this effect is non-linear). This is in contrast to the characteristics that make a firm systemically vulnerable and will be analysed more deeply later (see Table 7). Firms with a dualclass ownership structure also appear to be less systemically important. Even though, our composite measure of corporate governance is not statistically significant, the dual-class variable is a good proxy for the shareholder friendliness of a firm. The literature on financial firms shows that higher corporate governance is associated with greater alignment with shareholder goals, which in turn leads to more risk taking (Iqbal, Strobl and Vahamaa, 2015 and Anginer et al., 2018). ${ }^{12}$ The corollary is that firms with greater agency costs (and greater management control) contribute less to systemic risk due to bearing less risk and that is picked up here through our dual-class variable. These firms, typically, have two types of share with differential voting rights. Generally, a relatively small group of insiders enjoy disproportionate voting rights through their non-traded superior shares relative to ordinary shareholders (see Masulis et al, 2009; and Gompers et al., 2010 for more details). Thus, they are less likely to pursue high-risk projects to appease shareholders, reducing their impact on system-wide risk.

Unlike Van Cauwenberge et al. (2019)'s study of Dutch firms, we find no evidence the degree of firm internationalisation matters for its contribution to systemic risk. Both foreign sales and our crosslisting dummy are consistently insignificantly different from zero in all specifications. This probably reflects the greater size of the U.S. economy and the greater openness and reliance on international trade of the Dutch economy.

Within-firm variation in $\triangle \mathrm{CoVaR}$ over time appears to be largely unrelated to firm-level characteristics. Only debt maturity and liquidity are statistically different from zero in our analysis. More short-term debt increases systemic risk due to the difficulty in rolling over debts in periods of financial turmoil. ${ }^{13}$ These difficulties appear to outweigh any benefits (during normal times) from the more frequent monitoring associated with short-term debt financing. As in the case of MES, higher firm-level liquidity reduces its systemic risk.

The economic significance of these results tends to be smaller than those for the MES analysis. Though statistically significant, the economic impact of firm size, debt and asset tangibility is relatively

\footnotetext{
${ }^{12}$ Similarly, though not focussing on systemic risk, Beltratti and Stulz (2012) report that firms with better corporate governance fared worse during the global financial crisis.

${ }^{13}$ More reliance on short-term debt has been shown as an aggravating factor for individual firm-level risk during the 2007-08 crisis by Almeida et al. (2012) among others.
} 
small. A one standard deviation change in these variables is associated with changes in $\triangle \mathrm{CoVaR}$ of about $1 \%$ of its average or smaller. Only accounts payable and market share elicit economically large changes in $\Delta \mathrm{CoVaR}$ with estimated impacts of about $7 \%$ and $10 \%$ of average $\Delta \mathrm{CoVaR}$ respectively.

Once more, there is substantial intra-industry variation in the contribution to systemic risk. Now, we find that industries like manufacturing, energy and business equipment are the industries which contribute most to systemic downturns. Manufacturing tends to be labour intensive and negative shocks to this sector are likely to produce adverse effects for the real economy. The health of the Energy and business equipment sectors may be seen as leading indicators of the general economic health and negative news emanating from these industries may be forerunner to a downturn in the general economy.

\section{[Insert Table 5 about here]}

\subsection{Debt and systemic risk}

Given the statistical and economic significance of debt in many of our regressions (both between- and within-firms across the two dimensions of systemic risk) and the importance attached by the IMF (2019) to the level of corporate indebtedness to the financial system, we delve deeper into the relationship between systemic risk and debt. Firstly, we investigate if debt specialisation / diversification or greater dependence on external financing on the part of the borrower impacts on our systemic risk measures and results are reported in Table 6. Secondly, we look for possible non-linear effects in debt (both financial and trade) with relation to the financial size of the firm (Table 7), i.e. we want to answer the question if for a given debt level, do small and large firms have the same vulnerability to a systemic shock or contribute equally to a systemic event?

Panel A of Table 6 focuses on the relationship between MES and various aspects of debt financing within the firm. We only report the coefficients on the debt related variables, though all of the control variables in the previous analysis are included as controls. As before, we estimate a series of REWB regressions with the between-firm effects in columns labelled 1-6 and the within-firm effects reported in columns 7-12. The level of debt continues to have a positive relationship with the firm's MES, though it is not always statistically significant in the between-firm analysis, while debt maturity and accounts payable (trade credit owed) are consistently insignificant in this analysis. Focusing on the newly introduced variables, we find no evidence of a relationship between the measures of debt specialisation (or diversification) between firm vulnerability and systemic risk. Neither HHI (Herfindahl-Hirschman index of debt type usage) nor Excl. 90 (a dummy variable which takes a value of 1 if the firm obtains at least $90 \%$ of its debt from one debt type and 0 otherwise) is statistically different from zero, suggesting that debt diversification matters little to the type of firm affected by a systemic event. For between-firm differences, measures of dependence on external financing (EFD) and financial constraints are similarly unrelated to the vulnerability of firms to systemic shocks, but we 
do find evidence that EFD has a positive association with MES within the firm over time. Greater dependence on external financing renders a firm more sensitive to a system-wide shock. Finally, we find that accounts receivable and net trade credit are related to between-firm differences in MES. The trade finance literature implies that firms can be systemically important, regardless of whether they are net trade lenders or borrowers. The former group act as 'banks' for other non-financial firms and their importance is due to the credit that they provide, while the latter rely on that credit and may create systemic problems if and when they default on this debt. The vulnerability of firms with high trade credit linkages is similar to the 'balance sheet contagion' effects that is described as a shock propagation mechanism in Kiyotaki and Moore (2002). Both Hazama and Uesugi (2017), using an extensive network of Japanese firms, and Jacobsen and von Schedvin (2015) for Sweden provide empirical evidence of this type of default propagation through trade credit. Corporate defaults impact on trade creditors increasing their likelihood of default. Our results show that trade lenders are most at risk to a systemic shock, i.e. the more trade credit extended, the more vulnerable a firm is to a systemic event. This shows that it's not just connections with the financial system that determine a firm's systemic vulnerability but that, also, linkages between and among industrial firms can heighten the sensitivity to a systemic shock.

Turning to $\triangle \mathrm{CoVaR}$ and the firm's contribution to systemic risk, an interesting picture emerges. There is little evidence that the level of debt, debt maturity or debt specialisation are related to differences in $\triangle \mathrm{CoVaR}$ between firms. However, many of the other measures do matter but often, not in the way that they might contribute to the firm's individual risk. Dependence on external financing and financial constraints are negatively correlated to a firm's impact on the system by reducing their financial linkages and thus insulating the financial sector from their firm-specific shocks. Trade credit is important but the direction of the influence depends on the firm's interactions with the system as a whole. Firms that extend more trade credit, captured through accounts receivable and net trade credit, make a higher contribution to systemic risk, again showing that 'lenders' are more systemically important. A negative shock to such a company increases the risk of the system, acting like a nonmonetary liquidity effect. A downturn in the fortunes of such a firm makes it more difficult for others to operate given that trade credit may be restricted or more costly in the future. In contrast, accounts payable (which one would expect to be positively related to the risk of the individual company) is negatively related to a firm's systemic risk contribution. This result is somewhat puzzling but it may be that risky firms just receive less trade credit regardless of market conditions, implying that 'lenders' are well-positioned to differentiate between 'good' and 'bad' credit risks. The nonlinear effects explored in Table 7 shed more light upon this relationship.

For $\Delta \mathrm{CoVaR}$ and this dimension of systemic risk, the within-firm effects are quite different. Over time, increasing accounts payable and shorter maturity debt are associated with increases in the systemic contribution of a firm. Shorter debt maturity requires a more frequent rollover of the debt and hence increases the liquidity pressures on debt markets during a crisis. Increasing accounts payable 
means that firms are even more connected with other firms and the threat of default on debts by these companies are likely to drag others into the turmoil, through the type of corporate default transmission described in Hazama and Uesugi (2017).

\section{[Insert Table 6 about here]}

In Table 7, we analyse the interaction of debt and firm size. We divide firms into size terciles, with the top tercile being designated as large firms. We then create an indicator dummy variable which takes the value of one if the firm is large and zero otherwise. We interact this dummy variable with both financial and trade debt and, despite not being reported, all the control variables are included in the estimated regressions. Panel A of Table 7 presents results for the MES risk measure and, first, we focus on the between-firm estimates. As before, debt and accounts receivable are positively related to a firm's systemic vulnerability, but this is lower for big firms - the coefficient on the interaction terms are negative but only statistically significant for financial debt. This implies that, all other things equal, larger firms have greater capacity to carry the debt burden are more resilient in the face of a systemic crisis. Even though we don't find evidence of a direct relationship between MES and firm size, the latter is indirectly related to a firm's vulnerability through its interaction with debt, particularly financial debt. The within-firm estimates reveal a similar pattern. However, now all of the interaction terms are statistically significant, implying that larger firms are less vulnerable than smaller firms with the same amounts of financial debt and accounts receivable but are more vulnerable with the same amount of accounts payable, presumably due to larger firms being more influential in the market and having more extensive credit linkages or at least linkages of greater magnitude across industries.

With respect to $\triangle \mathrm{CoVaR}$ (Panel B), there is less compelling evidence that size matters. There is no new evidence garnered from the between-firm estimates, i.e. all the interaction terms are statistically insignificant. Within-firm estimates suggest that for equal levels of accounts receivables, larger firms contribute less to systemic risk. Their greater financial capacity appears to help them absorb the shock without transmitting it to the wider system. The opposite is true for accounts payable with the interaction term positive and statistically significant. Upon experiencing a tail event and for a given level of outstanding trade credit due to others, larger firms are more likely to generate systemic risk. Again this may be due to their greater linkages to other firms (both financial and industrial) and their influence upon the marketplace.

\section{[Insert Table 7 about here]}

In summary, we find a strong relationship between our systemic risk measures and both financial debt and trade credit. The presence of nonlinearities in these relationships between large and other firms reveals a nuanced influence of debt. For a given level of debt, larger firms are more resilient in the face of a systemic shock but their idiosyncratic negative shocks are associated with higher systemic contribution. The seemingly puzzling relationship between accounts payable and $\Delta \mathrm{CoVaR}$ 
reported earlier can be, at least in part, attributed to the oppositely signed correlation between the two variables for the largest and all other NFCs.

\subsection{Systemic risk over the lifecycle}

Regression results in Table 4 showed that firm age was an important determinant of a firm's MES. We want to investigate if this variable is a proxy for the firm lifecycle as it sometimes used as such in other studies, e.g. Faff et al. (2016) among others. Even though, firm age is not statistically significant in the $\Delta \mathrm{CoVaR}$ regressions, for completeness, we also investigate if there is a significant lifecycle effect in this dimension of systemic risk. We use the MLDA methodology of Faff et al. (2016) to classify firms into a lifecycle stage (as outlined earlier) and then estimate a series of REWB regressions with the birth stage being the omitted reference group. Our results are reported in Table $8^{14}$ and are consistent with the fact the firm age may be a proxy for a lifecycle effect. We find strong evidence of a lifecycle effect for MES - both between- and within-firms - but little or nothing with regards to $\triangle \mathrm{CoVaR}$. Focusing on MES, we find that relative to the birth stage, firms in each of the later stages of the lifecycle spectrum are more resilient to systemic risk and exhibit an inverted U-shaped pattern. Vulnerability to a systemic event is greatest for birth-stage firms and this declines as the firm progresses along the lifecycle with the peak resilience occurring in the mature stage. Thereafter, vulnerability again increases in the shake-out and decline stage but remains lower than in the birth stage and is not statistically different from the growth stage. In other words, a systemic crisis is most likely to affect younger, early-stage firms and firms who have already entered into their decline stages. This is consistent with the extant literature which has shown that beta and tail risk peak in early-stage firms and fall as firms age (see Chincarini et al., 2016; and Habib and Hasan, 2017). Younger firms are particularly dependent on external financing and are likely to be most adversely affected by turbulence and frictions in debt markets, particularly in securing bank loans at affordable rates. Economic downturns and recessions are also difficult times to release new products on the market and are likely to impact more negatively on new companies whose brand may not yet be recognisable to potential customers.

Relative to MES, there is little evidence of statistically significant differences in $\Delta \mathrm{CoVaR}$ across the lifecycle spectrum. However, there is a caveat. The estimated coefficient for mature stage firms is positive and statistically greater than for growth- and shake-out / decline- stage firms, providing some evidence that a large negative shock to a mature stage firm has greater negative repercussions for the wider economy than for these other groups. This is likely due to its greater influence and importance in the marketplace through its linkages to other firms. Otherwise, our results suggest that firms at all lifecycle stages have roughly similar association with the contribution to systemic events.

\footnotetext{
${ }^{14}$ All regressors from earlier regression are included as control variables with the exception of firm size, age and profitability which are used in the allocation of firms to each of the lifecycle stages using MLDA.
} 


\section{Conclusion}

This paper examines the systemic risk of large U.S. industrial firms and establishes that such firms can be of systemic importance. NFCs, through their interactions with the financial system and with each other, can both exhibit high vulnerability to a systemic shock and contribute to the systemic event through the transmission of its own shocks. This aspect of systemic risk has received relatively little attention in the academic literature and its role in propagating systemic events needs to be understood. We find that, generally, firms who are most vulnerable to a crisis are different from those who generate systemic risk but they share some common characteristics. As warned by IMF (2019), financial debt is positively associated with both dimensions of systemic risk which is of current importance given the record levels of corporate indebtedness and the declining credit quality of U.S. industrial firms. We also find evidence that trade debts - accounts receivable and payable - are related to systemic importance, particularly accounts receivable suggesting that providers of credit are relatively more crucial for the stability of the overall system. Even though, we find little evidence that firm size matters directly, there are sufficient nonlinear debt effects between large and other firms to show that size matters indirectly.

Firm-level characteristics associated with systemic risk are not confined to debt and the identification of these traits are likely to be important to financial market participants. Variables such as profitability, market share, liquidity and age are negatively related to systemic vulnerability. Firm age appears to be picking up a lifecycle effect as we find evidence that early-stage and decline-stage firms are more at risk from a systemic shock than growth- or mature-stage firms. A number of additional factors, such as firm size, a dual-class ownership structure and being a dividend payer are statistically significantly related to systemic contribution. Asset tangibility is an example of a factor that exerts differential effects at the individual and system level. Higher asset tangibility is typically found to reduce risk at the firm-level but we find that increases both dimensions of systemic risk, possibly due to the difficulty in realising their book values during a crisis episode, especially if the seller has been forced to divest these assets to deleverage.

Interestingly, characteristics that are found to be dominant in the banking literature play a limited or indirect effect for industrials. Bank size and corporate governance are always found to be strongly related to systemic risk among banks and non-bank financials and it's often argued that their prevalence is due to the 'too-big-to-fail' theory whereby markets expect large financials not to be allowed to fail in the interests of market stability. Without an equivalent expectation for the NFC sector, size and corporate governance appear to be less important.

So, what can be done to protect the financial system and wider economy from the systemic risk of industrial firms? Firstly, banks and investors need to be cognisant of this threat and the associated firm-level characteristics and must manage their exposures appropriately. Governments, regulators and policymakers can also take measures to build resilience in the system. Governments could remove or phase out the tax shield that debt financing currently enjoys, to eliminate the bias towards debt 
financing. However, the development of further policy in this area would require further analysis. The temptation to regulate industrials and their debt market activities may not be advisable as it may drive borrowing into a shadow-banking sector or into the hands of private lenders whose own resilience to a systemic shock is largely unknown and likely to aggravate market uncertainty during a downturn.

\section{References}

1. Acemoglu, D., Ozdaglar, A., Tahbaz-Salehi, A., 2015. Systemic risk and stability in financial networks. American Economic Review, 105, 564-608.

2. Acharya, V., Davydenko, S., Strebulaev, I., 2012. Cash holdings and credit risk. The Review of Financial Studies, 25, 3572-3609.

3. Acharya, V., Engle, R., Richardson, M., 2012. Capital shortfall: a new approach to ranking and regulating systemic risks. American Economic Review, 102, 59-64.

4. Acharya, V., Pedersen, L., Philippon, T., Richardson, M., 2017. Measuring systemic risk. Review of Financial Studies, 30 (1), 2-47.

5. Adrian, T., Brunnermeier, M., 2016. CoVaR. American Economic Review, 116, 1705-1741.

6. Aggarwal, R., Erel, I., Ferreira, M., Matos, P., 2011. Does governance travel around the world? Evidence from institutional investors. Journal of Financial Economics, 100, 154-181.

7. Akhtaruzzaman, M., Shamsuddin, A., 2016. International contagion through financial versus non-financial firms. Economic Modelling, 59, 143-163.

8. Almeida, H., M. Campello, B. Laranjeira, and Weisberner, S., 2012, Corporate debt maturity and the real effects of the 2007 credit crisis, Critical Finance Review 1, 3-58.

9. Anderson, R., Duru, A., and Reeb, D, 2009. Founders, heirs, and corporate opacity in the United States. Journal of Financial Economics, 92, 205-222.

10. Anderson, R., Reeb, D., and Zhao, W, 2012. Family-controlled firms and informed trading: Evidence from short sales. Journal of Finance, 67, 351-385.

11. Andries, A.M., Nistor. S., 2016. Systemic risk, corporate governance and regulation of banks across emerging countries. Economics Letters, 144, 59-63.

12. Anginer, D., Demirguc-Kunt, A., Huizinga, H., Ma, K., 2018. Corporate governance of banks and financial fragility. Journal of Financial Economics, 130, 327-346.

13. Beck, T., Demirguc-Kunt, A., and Maksimovic, V., 2004. Bank competition, financing and access to credit. Journal of Money, Credit and Banking, 627-648.

14. Behrens, K., Corcos, Mion, G., 2013. Trade crisis? What trade crisis? The Review of Economics and Statistics, 95, 702-709.

15. Bell, A., Jones, K., 2015. Explaining fixed-effects: random effects modelling of time-series cross-sectional and panel data. Political Science Research and Methods, 3, 133-153.

16. Beltratti, A., Stulz, R., 2012. The credit crisis around the globe: why did some banks perform better? Journal of Financial Economics, 105, 1-17.

17. Benoit, S., Colletaz, G., Hurlin, C., and Perignon, C, 2013. A theoretical and empirical comparison of systemic risk measures. Working paper, University of Orleans.

18. Billio, M., Getmansky, M., Lo, A.W., Pelizzon, L., 2012. Econometric measures of connectedness and system risk in the finance and insurance sectors. Journal of Financial Economics, 104, 535-559.

19. Bisias, D., Flood, M., Lo, A., Valavanis, S., 2012. A survey of systemic risk analytics. Annual Review of Financial Economics, 4, 255-296.

20. Bostandzic, D., Weiß, G., 2018. Why do some banks contribute more to global systemic risk? Journal of Financial Intermediation, 35, 17-40.

21. Brav, A., Graham, J., Harvey, C., and Michaely, R, 2005. Payout policy in the $21^{\text {st }}$ century. Journal of Financial Economics, 77, 483-527.

22. Brownlees, C., and Engle, R., 2017. SRISK: a conditional capital shortfall measure of systemic risk. The Review of Financial Studies, 30 (1), 48-79.

23. Brunnermeier, M., 2009. Deciphering the liquidity and credit crunch of 2007-09. Journal of Economic Perspectives, 23, 77-100. 
24. Brunnermeier, M., Pedersen, L., 2009. Market liquidity and funding liquidity. The Review of Financial Studies, 22, 2201-2238.

25. Calluzzo, P., Dong, G., 2015. Has the financial system become safer after the crisis? The changing nature of financial institution risk. Journal of Banking and Finance, 53, 233-248.

26. Celik, S., Demirtas, G., Isaksson, M., 2020. Corporate bond market trends, emerging risks and monetary policy. OECD Capital Market Series, Paris. Available at: http://www.oecd.org/corporate/Corporate-Bond-Market-Trends-Emerging-Risks-andMonetary-Policy.htm

27. Chandar, N., Patro, D., and Yezegel, A, 2009. Crises, contagion, and cross-listings. Journal of Banking and Finance, 33, 1709-1729.

28. Chincarini, L., Kim, D., and Moneta, F, 2016. The life cycle of beta. Working paper, University of San Francisco School of Management.

29. Chung, K, 1989. The impact of the demand volatility and leverage on the systematic risk of common stocks. Journal of Business Finance and Accounting, 16, 343-360.

30. Colla, P., Ippolito, F., and Li, K, 2013. Debt specialization. Journal of Finance, 68, 2117-2141.

31. Das, S., Duffie, D., Kapadia, N., and Saita, L, 2007. Common failings: how corporate defaults are correlated. Journal of Finance, 93-117.

32. De Sola Perea, M., Dunne, P., Puhl, M., Reininger, M., 2019. Sovereign bond-backed securities: A VAR-for-VaR and marginal expected shortfall approach. Journal of Empirical Finance, 53, 33-52.

33. Demirguc-Kunt, A., Maksimovic, V., 2001. Firms as financial intermediaries: evidence from trade credit data. Policy Research working paper; no. WPS 2696. Washington, DC: World Bank.

34. Drehmann, M., Tarashev, N., 2013. Measuring the systemic risk of interconnected banks. Journal of Financial Intermediation, 22, 586-607.

35. Dungey, M., Flavin, T., Lagoa-Varela, D. (2020). Are banking shocks contagious? Evidence from the Eurozone. Journal of Banking and Finance (In press).

36. Dungey, M., Gajurel, D., 2015. Contagion and banking crisis - international evidence for 2007 - 09. Journal of Banking and Finance, 60, 271-283.

37. Dungey, M., Luciani, M., Veredas, D., 2018. Systemic risk in the US: Interconnectedness as a circuit breaker. Economic Modelling, 71, 305-315.

38. Engle, C., and Wang, J, 2011. International trade in durable goods: understanding volatility, cyclicality, and elasticities. Journal of International Economics, 83, 37-52.

39. Faff, R., Kwok, W., Podolski, E., and Wong, G, 2016. Do corporate policies follow a lifecycle? Journal of Banking and Finance, 69, 95-107.

40. Ferris, S., Jayaraman, N., and Makhija, A, 1997. The response of competitors to announcements of bankruptcy: an empirical examination of contagion and competitive effects. Journal of Corporate Finance, 3, 367-395.

41. Gahlon, J. and Gentry, J, 1982. On the relationship between systematic risk and the degrees of operating and financial leverage. Financial Management, 11, 15-23.

42. Giglio, S., 2011. Credit default swap spreads and systemic financial risk. ESRB working paper no. 15, European Systemic Risk Board. Frankfurt, Germany.

43. Giratis, L., Kapetanios, G., Wetherilt, A., Zikes, F., 2016. Estimating the dynamics and persistence of financial networks, with an application to the sterling money market. Journal of Applied Econometrics, 31, 58-84.

44. Gompers, P., Ishii, J., and Metrick, A, 2010. An analysis of dual-class companies in the United States. The Review of Financial Studies, 23, 1051-1088.

45. Gorton G (2009). Information, liquidity and the (ongoing) panic of 2007. American Economic Review, 99, 567-572.

46. Guntay, L., and Kupiec, P., 2016. Testing for systemic risk using stock returns. Journal of Financial Services Research, 49, 203-227.

47. Habib, A., and Hasan, M, 2017. Firm life cycle, corporate risk taking and investor sentiment. Accounting and Finance, 57, 465-497.

48. Hadlock, C., and Pierce, J, 2010. New evidence on measuring financing constraints: moving beyond the KZ index. The Review of Financial Studies, 23, 1909-1940. 
49. Hamada, R, 1972. The effect of the firm's capital structure on the systematic risk of common stocks. Journal of Finance, 27, 435-452.

50. Hazama, M., and Uesugi, I., 2017. Measuring the systemic risk in interfirm transaction networks. Journal of Economic Behavior \& Organization, 137, 259-281.

51. Hoberg, G., Phillips, G., and Prabhala, G, 2014. Product market threats, payouts, and financial flexibility. Journal of Finance, 69, 293-324.

52. Huang, X., Zhou, H., Zhu, H., 2009. A framework for assessing the systemic risk of major financial institutions. Journal of Banking and Finance, 33, 2036-2049.

53. International Monetary Fund, 2019. Global Financial Stability Report: Lower for Longer. Washington, DC, October.

54. Iqbal, J., Strobl, S., and Vahamaa, S, 2015. Corporate governance and the systemic risk of financial institutions. Journal of Economics and Business, 82, 42-61.

55. Jacobson, T., and von Schedvin, 2015. Trade credit and the propagation of corporate failure: an empirical analysis. Econometrica, 83, 1315-1371.

56. John, K., Knyazeva, A., and Knyazeva, D, 2015. Governance and payout precommitment. Journal of Corporate Finance, 33, 101-117.

57. Jorion, P., 2007. Risk management for hedge funds with position information. Journal of Portfolio Management, 34, 127-134.

58. Jovanovic, B., and Rousseau, P, 2001. Why wait? A century of life before IPO. American Economic Review, 91, 336-341.

59. Kiyotaki, N., and Moore, J, 2002. Balance-sheet contagion. American Economic Review, 92, 46-50.

60. Klingebiel, D., Krozner, R., Laeven, L., 2007. Banking crises, financial dependence, and growth. Journal of Financial Economics, 84, 187-228.

61. Korinek, A, Roitman, A, Végh, C.A., 2010. Decoupling and recoupling. American Economic Review, 100, 393-397.

62. Laeven, L., Ratnovski, L. and Tong, H, 2016. Bank size, capital, and systemic risk: some international evidence. Journal of Banking and Finance, 69, S25-S34.

63. Langfield, S., Liu, Z., Ota, T., 2014. Mapping the UK interbank system. Journal of Banking and Finance, 45, 288-303.

64. Loughran, T., and Ritter, J, 2004. Why has IPO underpricing changed over time? Financial Management, Autumn, 5-37.

65. Love, I., Preve, L., and Sarria-Allende, V, 2007. Trade credit and bank credit: evidence from recent financial crises. Journal of Financial Economics, 83, 453-469.

66. Masulis, R.W., Wang, C., Xie, F., 2009. Agency problems at dual-class companies. Journal of Finance, 64, 1697-1727.

67. Mayordomo, S., Rodriquez-Moreno, M., Peña, J.I., 2014. Derivatives holdings and systemic risk in the U.S. banking sector. Journal of Banking and Finance, 45, 84-104.

68. Mitton, T, 2002. A cross-firm analysis of the impact of corporate governance on the East Asian financial crisis. Journal of Financial Economics, 64, 215-241.

69. Nijskens, R., and Wagner, W., 2011. Credit risk transfer activities and systemic risk: How banks became less risky individually but posed greater risks to the financial system at the same time. Journal of Banking and Finance, 35, 1391-1398.

70. Pais, A., and Stork, P, 2013. Bank size and systemic risk. European Financial Management, 19, 429-451.

71. Parigi, B., Pelizzon, L., von Thadden, E, 2017. A corporate governance asset-pricing model: some theory and evidence. Working paper, University of Padova.

72. Poledna, S., Hinteregger, A., Thurner, S., 2018. Identifying systemically important companies by using the credit network of an entire nation. Entropy, 20 (10), 792.

73. Rajan, R. and Zingales, L, 1998. Financial dependence and growth. American Economic Review, 88, 559-586.

74. Riddick, L., Whited, T., 2009. The corporate propensity to save. Journal of Finance, 64 (4), 1729-1766.

75. Sarkissian, S., and Schill, M, 2009. Are there permanent valuation gains to overseas listings? The Review of Financial Studies, 22, 371-412. 
76. Schlueter, T., and Sievers, S, 2014. Determinants of market beta: the impacts of firm-specific accounting figures and market conditions. Review of Quantitative Finance and Accounting, 42, 535-570.

77. Shleifer, A., Vishny, R., 2011. Fire sales in finance and macroeconomics. Journal of Economic Perspectives, 25 (1), 29-48.

78. Subrahmanyan, M., and Thomadakis, S, 1980. Systematic risk and the theory of the firm. The Quarterly Journal of Economics, 94, 437-451.

79. Tarashev, N., Borio, C., Tsatsaronis, K., 2010. Attributing systemic risk to individual institutions. BIS Working Papers 308.

80. Van Cauwenberge, A., Vancauteren, M., Braekers, R., Vandemaele, S., 2019. International trade, foreign direct investments and firms' systemic risk: Evidence from the Netherlands. Economy Modelling, 81, 361-386.

81. Van de Leur, M., Lucas, A., Seeger, N., 2017. Network, market, and book-based systemic risk rankings. Journal of Banking and Finance, 78, 84-90.

82. Varotto, S., Zhao, L., 2018. Systemic risk and bank size. Journal of International Money and Finance, 82, 45-70.

83. Wagner, W., 2010. Diversification at financial institutions and systemic crises. Journal of Financial Intermediation, 19, 373-386. 
Table 1: Variable description and summary statistics

\begin{tabular}{|c|c|c|c|c|c|c|c|c|c|}
\hline \multirow[t]{2}{*}{ Variable } & \multirow[t]{2}{*}{ Description } & & & & \multicolumn{3}{|c|}{ Standard deviation } & \multirow[t]{2}{*}{ Coverage } & \multirow[t]{2}{*}{ Source(s) } \\
\hline & & Mean & Min & Max & Total & B-SD & W-SD & & \\
\hline MES & Systemic risk vulnerability of firm & 2.40 & $(0.68)$ & 9.21 & 1.90 & 0.84 & 1.72 & $2005-2011$ & \multirow{2}{*}{$\begin{array}{l}\text { Datastream, Worldscope and } \\
\text { author calculations }\end{array}$} \\
\hline$\Delta \mathrm{CoVar}$ & Systemic risk contribution of firm & 1.26 & $(0.45)$ & 4.42 & 0.71 & 0.22 & 0.67 & $2005-2011$ & \\
\hline Corporate governance & Corporate governance scores in $0-100$ range & 0.69 & 0.27 & 0.90 & 0.08 & 0.07 & 0.04 & $2004-2008$ & Aggarwal et al. (2011) \\
\hline Dual-class firm & 1 if the firm is a dual-class share firm & 0.09 & 0.00 & 1.00 & 0.29 & 0.29 & 0.00 & $2004-2010$ & Gompers et al. (2010) \\
\hline Family firm & 1 if the firm is a family firm & 0.19 & 0.00 & 1.00 & 0.39 & 0.39 & 0.06 & $2004-2010$ & Anderson et al. $(2009,2012)$ \\
\hline Size & Log of book assets in billions of \$US & 20.18 & 0.001 & 797.8 & 50.98 & 50.06 & 7.99 & $2004-2010$ & Worldscope \\
\hline Cross-listing & 1 if the firm is cross-listed abroad & 0.16 & 0.00 & 1.00 & 0.37 & 0.37 & 0.05 & $2004-2010$ & Sarkissian and Schill (2009) \\
\hline Debt & Total debt to market capitalization & 0.30 & 0.00 & 2.86 & 0.42 & 0.35 & 0.24 & $2004-2010$ & Worldscope \\
\hline Debt maturity & Long-term debt to total debt & 0.77 & 0.00 & 1.00 & 0.31 & 0.24 & 0.20 & $2004-2010$ & Worldscope \\
\hline HHI & Herfindahl-Hirschman index of debt type usage & 0.69 & 0.15 & 1.00 & 0.25 & 0.21 & 0.15 & $2004-2009$ & Colla et al. (2013) \\
\hline Excl. 90 & $\begin{array}{l}1 \text { if the firm obtains at least } 90 \% \text { of its debt } \\
\text { from one debt type }\end{array}$ & 0.43 & 0.00 & 1.00 & 0.50 & 0.39 & 0.32 & $2004-2009$ & Colla et al. (2013) \\
\hline Accounts payable & Accounts payable to assets & 0.09 & 0.00 & 0.43 & 0.08 & 0.08 & 0.02 & $2004-2010$ & Worldscope \\
\hline Accounts receivable & Accounts receivable to assets & 0.13 & 0.00 & 0.45 & 0.09 & 0.08 & 0.03 & $2004-2010$ & Worldscope \\
\hline Net trade credit & Accounts receivables less payables to assets & 0.04 & $(0.43)$ & 0.43 & 0.10 & 0.09 & 0.03 & $2004-2010$ & Worldscope \\
\hline Asset tangibility & Gross property, plant and equipment to assets & 0.27 & 0.01 & 0.88 & 0.22 & 0.21 & 0.04 & $2004-2010$ & Worldscope \\
\hline R\&D expense & R\&D expense to assets & 0.03 & 0.00 & 0.34 & 0.05 & 0.04 & 0.01 & $2004-2010$ & Worldscope \\
\hline Market share & Firm sales to total industry sales & 0.03 & 0.00 & 0.52 & 0.05 & 0.05 & 0.01 & $2004-2010$ & Worldscope \\
\hline Product market fluidity & Proxy for product market competition & 6.31 & 0.41 & 21.04 & 3.42 & 2.99 & 1.64 & $2004-2010$ & Hoberg et al. (2014) \\
\hline Dividend payer & 1 if the firm pays a dividend, 0 otherwise & 0.70 & 0.00 & 1.00 & 0.46 & 0.43 & 0.17 & $2004-2010$ & Worldscope \\
\hline Cash holdings & Cash to assets & 0.13 & 0.00 & 5.85 & 0.21 & 0.16 & 0.13 & $2004-2010$ & Worldscope \\
\hline Profitability & Operating income less depreciation to assets & 0.09 & $(0.26)$ & 0.45 & 0.11 & 0.09 & 0.06 & $2004-2010$ & Worldscope \\
\hline Profit volatility & $\begin{array}{l}\text { 5-year centered standard deviation of } \\
\text { profitability }\end{array}$ & 0.05 & 0.00 & 0.73 & 0.09 & 0.08 & 0.05 & $2004-2010$ & Worldscope \\
\hline Liquidity & Current assets to current liabilities & 3.58 & 0.04 & 17.04 & 2.23 & 1.97 & 1.06 & $2004-2010$ & Worldscope \\
\hline Growth opportunities & Market to book of assets & 3.65 & $(11.77)$ & 26.42 & 4.01 & 2.47 & 3.16 & $2004-2010$ & Worldscope \\
\hline Lifecycle indicator & Life-cycle indicator based on MLDA & 2.92 & 1.00 & 4.00 & 0.88 & 0.55 & 0.70 & $2004-2010$ & Worldscope \\
\hline $\begin{array}{l}\text { External financing } \\
\text { dependence }\end{array}$ & $\begin{array}{l}\text { Capital expenditures less cash flow from } \\
\text { operations divided by capital expenditures }\end{array}$ & $(2.78)$ & $(10.82)$ & $(6.86)$ & 3.38 & 2.99 & 1.69 & $2004-2010$ & Worldscope \\
\hline Financing constraints & $\begin{array}{l}\text { Calculated as }[-0.737 * \log (\text { total assets })]+ \\
{\left[0.043 * \log (\text { total assets })^{2}\right]-(0.040 * \text { Age })}\end{array}$ & $(2.67)$ & $(4.74)$ & 7.05 & 1.21 & 1.25 & 0.20 & $2004-2010$ & Worldscope \\
\hline
\end{tabular}




\begin{tabular}{|c|c|c|c|c|c|}
\hline \multicolumn{6}{|l|}{ Table 2} \\
\hline \multirow{2}{*}{\multicolumn{6}{|c|}{$\begin{array}{l}\text { This table lists the top ten riskiest and least risky firms base } \\
\text { MES: Top } 10\end{array}$}} \\
\hline & & & & & \\
\hline Company & Industry & $\begin{array}{l}\text { MES/ } \Delta \text { Covar } \\
\text { Rank }\end{array}$ & Company & Industry & $\begin{array}{l}\Delta \text { Covar/MES } \\
\text { Rank }\end{array}$ \\
\hline OfficeMax & Retail & $1 / 180$ & Anadarko Petroleum & Energy & $1 / 85$ \\
\hline AK Steel & Manufacturing & $2 / 116$ & E I du Pont de Nemours & Chemicals & $2 / 157$ \\
\hline National Oilwell Varco & Energy & $3 / 11$ & Sigma-Aldrich & Chemicals & $3 / 207$ \\
\hline Sprint Nextel & Retail & $4 / 345$ & Williams Companies & Energy & $4 / 66$ \\
\hline Cliffs Natural Resources & Other & $5 / 72$ & Automatic Data Processing & Buss Equip & $5 / 293$ \\
\hline Office Depot & Retail & $6 / 259$ & Illinois Tool Works & Manufacturing & $6 / 196$ \\
\hline Terex & Manufacturing & $7 / 73$ & Air Products \& Chemicals & Chemicals & $7 / 191$ \\
\hline United States Steel & Manufacturing & $8 / 118$ & Northrop Grumman & Manufacturing & $8 / 266$ \\
\hline Manitowoc & Manufacturing & $9 / 85$ & United Technologies & Manufacturing & $9 / 230$ \\
\hline Brunswick & Manufacturing & $10 / 209$ & National Oilwell Varco & Energy & $10 / 3$ \\
\hline \multicolumn{3}{|c|}{ MES: Bottom 10} & \multicolumn{3}{|c|}{$\Delta$ Covar: Bottom 10} \\
\hline Company & Industry & $\begin{array}{l}\text { MES/ } \Delta \text { Covar } \\
\text { Rank }\end{array}$ & Company & Industry & $\begin{array}{l}\Delta \text { Covar/MES } \\
\text { Rank }\end{array}$ \\
\hline Perrigo & Healthcare & $358 / 320$ & F5 Networks & Buss Equip & $358 / 204$ \\
\hline ConAgra Foods & Nondurables & $359 / 354$ & pricelinecom & Other & $359 / 173$ \\
\hline Johnson \& Johnson & Retail & $360 / 152$ & Amazoncom & Retail & $360 / 222$ \\
\hline Kellogg Company & Nondurables & $361 / 185$ & Lennar & Other & $361 / 193$ \\
\hline Hormel Foods & Nondurables & $362 / 200$ & Dollar Tree & Retail & $362 / 351$ \\
\hline Campbell Soup & Nondurables & $363 / 139$ & Newmont Mining & Other & $363 / 328$ \\
\hline The Clorox Company & Chemicals & $364 / 328$ & Expedia & Other & $364 / 15$ \\
\hline Colgate-Palmolive & Chemicals & $365 / 272$ & The Interpublic Group & Other & $365 / 71$ \\
\hline Kimberly-Clark & Manufacturing & $366 / 181$ & RadioShack & Retail & $366 / 172$ \\
\hline General Mills & Nondurables & $367 / 351$ & Netflix & Other & $367 / 255$ \\
\hline
\end{tabular}




\begin{tabular}{|c|c|c|c|c|c|c|c|}
\hline \multicolumn{8}{|c|}{$\begin{array}{l}\text { This tables compares the average firm in the top (most risky) and bottom (least risky) systemic risk quartiles. The number } \\
\text { of firm-years across quartiles is not uniform because of clustering at zero for MES. Systemic risk is measured using } \\
\text { marginal expected shortfall (MES) and } \Delta \text { CoVar.. All other variables are defined in Table } 1 \text {. The column labeled "LPM } \\
\text { coefficients" presents coefficients from a linear probability model where the dependent variable is } 1 \text { if firm belongs in the } \\
\text { top risk quartile, and } 0 \text { if it belongs in the bottom quartile. } * * *, * * \text {, and } * \text { denotes statistical significance at the } 1,5 \text {, and } \\
10 \% \text { levels, respectively. }\end{array}$} \\
\hline & & \multicolumn{6}{|c|}{ Systemic risk measure } \\
\hline & & \multicolumn{3}{|c|}{ MES } & \multicolumn{3}{|c|}{$\Delta \mathrm{CoVaR}$} \\
\hline & & $\begin{array}{c}\text { Firms in } \\
\text { highest } \\
\text { risk } \\
\text { quartile } \\
\end{array}$ & $\begin{array}{c}\text { Firms in } \\
\text { lowest } \\
\text { risk } \\
\text { quartile } \\
\end{array}$ & $\begin{array}{c}\text { LPM } \\
\text { coefficients }\end{array}$ & $\begin{array}{c}\text { Firms in } \\
\text { highest } \\
\text { risk } \\
\text { quartile } \\
\end{array}$ & $\begin{array}{c}\text { Firms in } \\
\text { lowest } \\
\text { risk } \\
\text { quartile } \\
\end{array}$ & $\begin{array}{c}\text { LPM } \\
\text { coefficients }\end{array}$ \\
\hline \multicolumn{2}{|c|}{$\#$ of firm-year observations in each quartile $\rightarrow$} & 454 & 1,174 & & 629 & 629 & \\
\hline Systemic risk & Systemic risk & 5.03 & 0.73 & & 2.23 & 0.48 & \\
\hline Size & Size (US \$ billions) & 14.44 & 21.11 & $0.039 *$ & 23.82 & 14.81 & $0.036^{* * * *}$ \\
\hline \multirow{3}{*}{$\begin{array}{l}\text { Corporate } \\
\text { governance }\end{array}$} & Corporate governance & 0.70 & 0.68 & $(0.005)$ & 0.72 & 0.68 & 0.080 \\
\hline & Dual-class share firm & 0.08 & 0.09 & 0.016 & 0.07 & 0.10 & $(0.019)$ \\
\hline & Family firm & 0.16 & 0.19 & $(0.010)$ & 0.18 & 0.21 & $0.028^{*}$ \\
\hline \multirow{5}{*}{$\begin{array}{l}\text { Financial leverage } \\
\text { and trade finance }\end{array}$} & Debt & 0.45 & 0.22 & $(0.054)$ & 0.25 & 0.26 & $(0.012)$ \\
\hline & Debt maturity & 0.83 & 0.76 & $(0.000)$ & 0.77 & 0.76 & $(0.005)$ \\
\hline & Debt specialization & 0.69 & 0.69 & 0.005 & 0.68 & 0.70 & 0.057 \\
\hline & Accounts payable & 0.09 & 0.09 & $(0.282)^{*}$ & 0.08 & 0.09 & $(0.189)^{*}$ \\
\hline & Accounts receivable & 0.13 & 0.13 & $(0.010)$ & 0.13 & 0.12 & $0.379 * * *$ \\
\hline \multirow[t]{2}{*}{ Internationalization } & Cross-list & 0.11 & 0.19 & $(0.034)^{*}$ & 0.18 & 0.14 & $(0.003)$ \\
\hline & Foreign sales & 0.35 & 0.30 & 0.031 & 0.36 & 0.32 & $(0.013)$ \\
\hline \multirow{4}{*}{$\begin{array}{l}\text { Lifecycle: proportion } \\
\text { of observations in top } \\
\text { and bottom risk } \\
\text { quartile for each } \\
\text { lifecycle stage }\end{array}$} & Introduction-stage & 0.54 & 0.28 & Reference & 0.23 & 0.28 & Reference \\
\hline & Growth-stage & 0.25 & 0.33 & 0.021 & 0.26 & 0.26 & $(0.040)^{*}$ \\
\hline & Mature-stage & 0.18 & 0.26 & $(0.022)$ & 0.29 & 0.21 & $(0.035)$ \\
\hline & $\begin{array}{l}\text { Shake-out/decline- } \\
\text { stage }\end{array}$ & 0.28 & 0.28 & 0.009 & 0.19 & 0.29 & $(0.036)$ \\
\hline Age & Age of firm & 36.73 & 36.56 & $(0.008)$ & 37.76 & 32.66 & 0.014 \\
\hline \multicolumn{2}{|c|}{ Research and development } & 0.03 & 0.03 & $0.402 * *$ & 0.03 & 0.03 & $\begin{array}{ll}(0.056) \\
\end{array}$ \\
\hline Asset tangibility & Asset tangibility & 0.34 & 0.26 & 0.044 & 0.29 & 0.25 & $0.136 * * *$ \\
\hline \multirow{2}{*}{$\begin{array}{l}\text { Industry and product } \\
\text { market competition }\end{array}$} & Market share & 0.02 & 0.03 & $(0.497)^{*}$ & 0.03 & 0.02 & $(0.392) * *$ \\
\hline & $\begin{array}{l}\text { Product market } \\
\text { fluidity }\end{array}$ & 6.32 & 6.26 & $(0.002)$ & 6.30 & 6.69 & $(0.002)$ \\
\hline Dividend policy & Dividend payer & 0.67 & 0.70 & $(0.020)$ & 0.76 & 0.64 & $(0.000)$ \\
\hline \multirow{2}{*}{ Liquidity } & Cash holdings & 0.21 & 0.09 & $0.130^{*}$ & 0.13 & 0.16 & $(0.101)$ \\
\hline & $\mathrm{CA} / \mathrm{CL}$ & 3.28 & 3.47 & 0.002 & 3.51 & 3.65 & 0.004 \\
\hline \multirow{3}{*}{$\begin{array}{l}\text { Profitability and } \\
\text { growth opportunities }\end{array}$} & Profitability & 0.05 & 0.11 & $(0.025)$ & 0.11 & 0.09 & $(0.092)$ \\
\hline & Profit volatility & 0.07 & 0.05 & $(0.226)$ & 0.05 & 0.05 & 0.082 \\
\hline & Growth opportunities & 3.03 & 4.05 & 0.002 & 3.82 & 3.99 & $(0.002)$ \\
\hline \multirow{2}{*}{$\begin{array}{l}\text { External financing } \\
\text { dependence and } \\
\text { financing constraints }\end{array}$} & EFD & $(1.30)$ & $(3.18)$ & $(0.003)$ & $(2.70)$ & $(2.92)$ & $(0.004)$ \\
\hline & Financing constraints & 5.53 & 5.50 & $(0.048)$ & 5.69 & 5.45 & $0.033^{*}$ \\
\hline \multirow{10}{*}{$\begin{array}{l}\text { Industry sectors: } \\
\text { proportion of } \\
\text { observations in top } \\
\text { and bottom risk } \\
\text { quartile for each } \\
\text { industry sector }\end{array}$} & $\begin{array}{l}\text { Consumer non- } \\
\text { durables }\end{array}$ & 0.16 & 0.28 & Reference & 0.20 & 0.27 & Reference \\
\hline & Consumer durables & 0.39 & 0.29 & 0.122 & 0.36 & 0.21 & $0.225 * * *$ \\
\hline & Manufacturing & 0.41 & 0.29 & 0.018 & 0.30 & 0.22 & $0.076 * * *$ \\
\hline & Energy & 0.45 & 0.28 & $(0.007)$ & 0.35 & 0.14 & $0.085^{* * * *}$ \\
\hline & Chemicals & 0.15 & 0.27 & 0.012 & 0.31 & 0.24 & 0.054 \\
\hline & Business Equipment & 0.23 & 0.29 & $(0.050)^{*}$ & 0.25 & 0.24 & 0.095 *** \\
\hline & Telecom & 0.16 & 0.29 & $(0.005)$ & 0.20 & 0.20 & $0.080^{*}$ \\
\hline & Retail & 0.15 & 0.28 & $(0.011)$ & 0.18 & 0.32 & 0.025 \\
\hline & Healthcare & 0.04 & 0.29 & $(0.115)^{* *}$ & 0.21 & 0.30 & 0.002 \\
\hline & Other & 0.37 & 0.29 & 0.017 & 0.27 & 0.25 & $0.067 * *$ \\
\hline
\end{tabular}




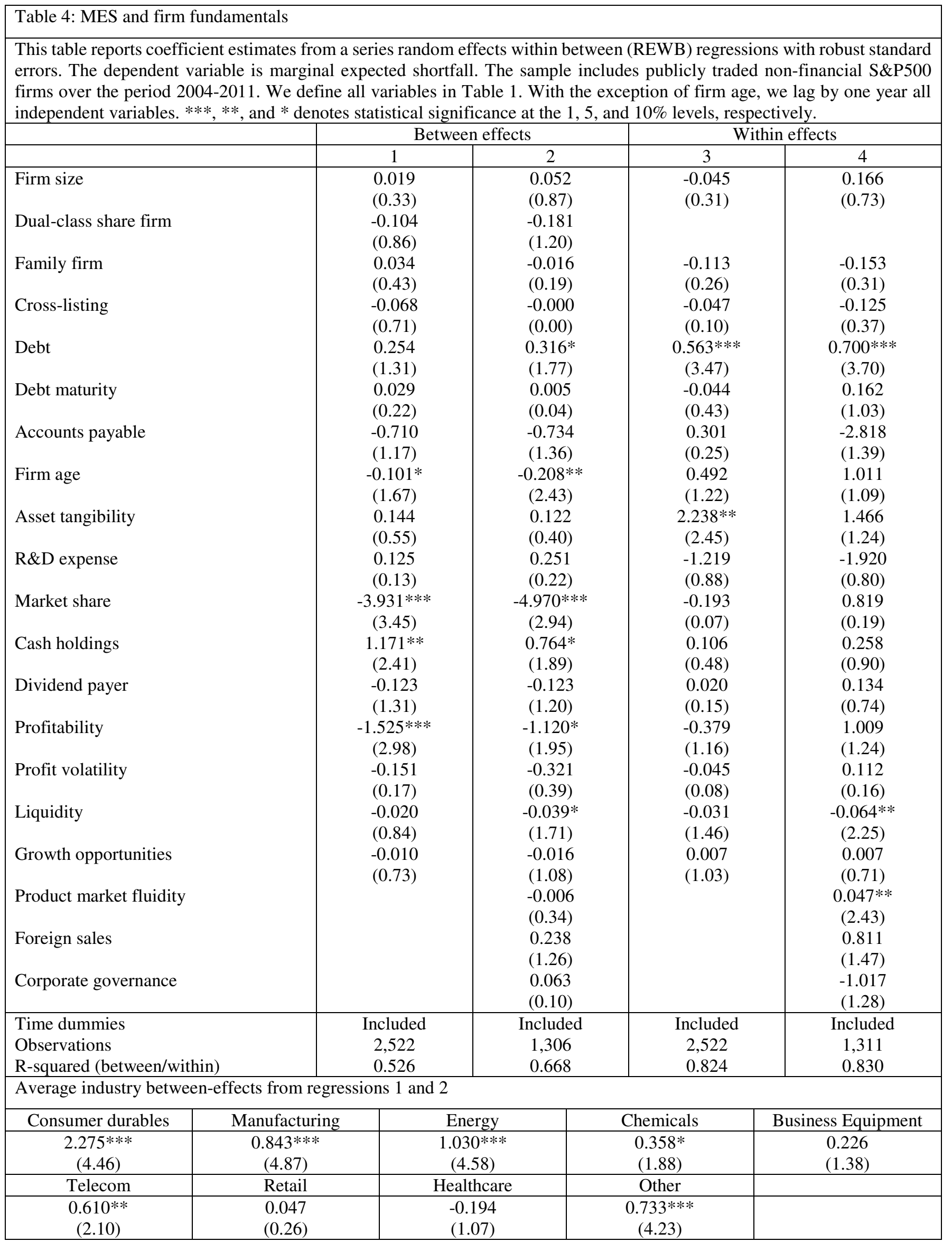




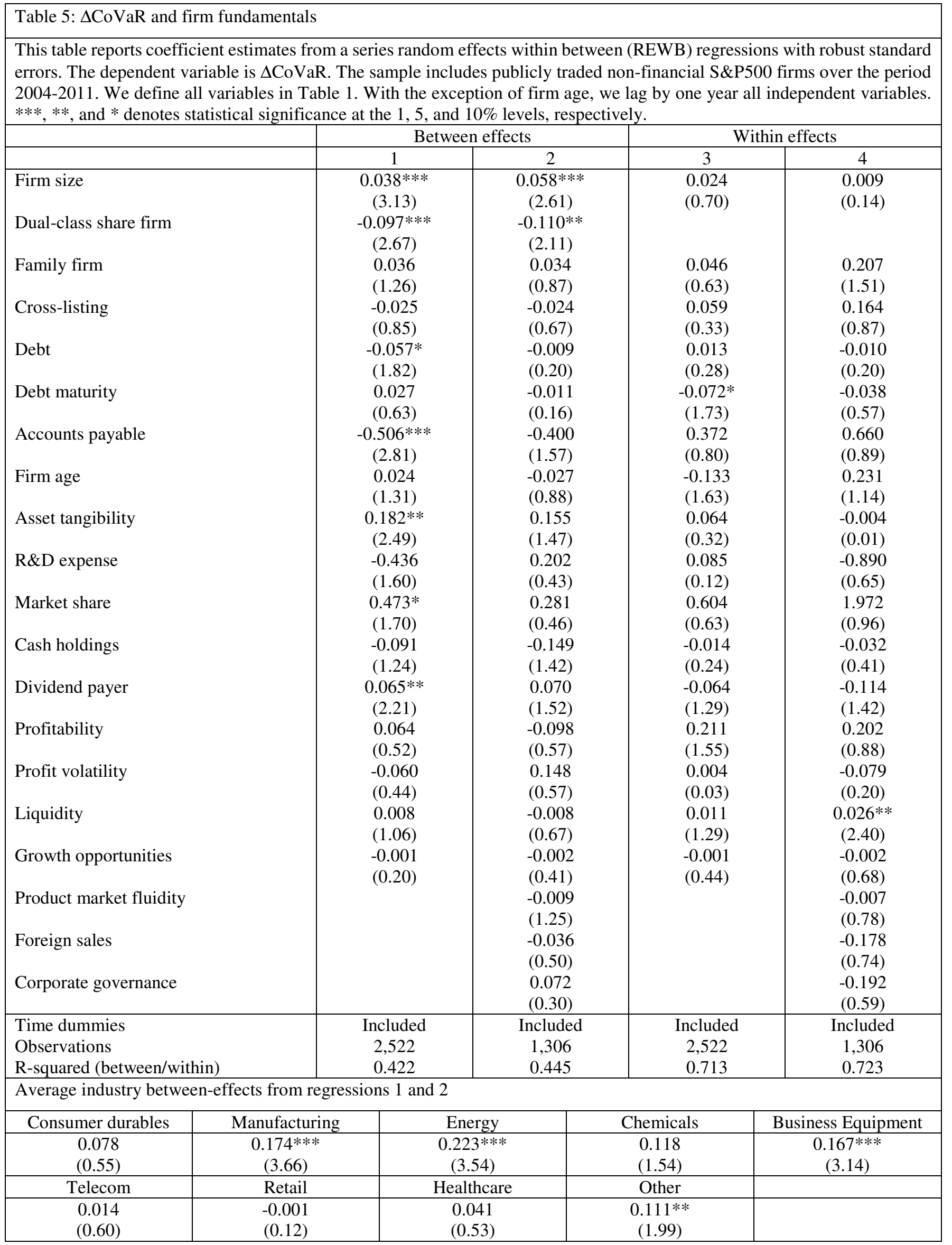




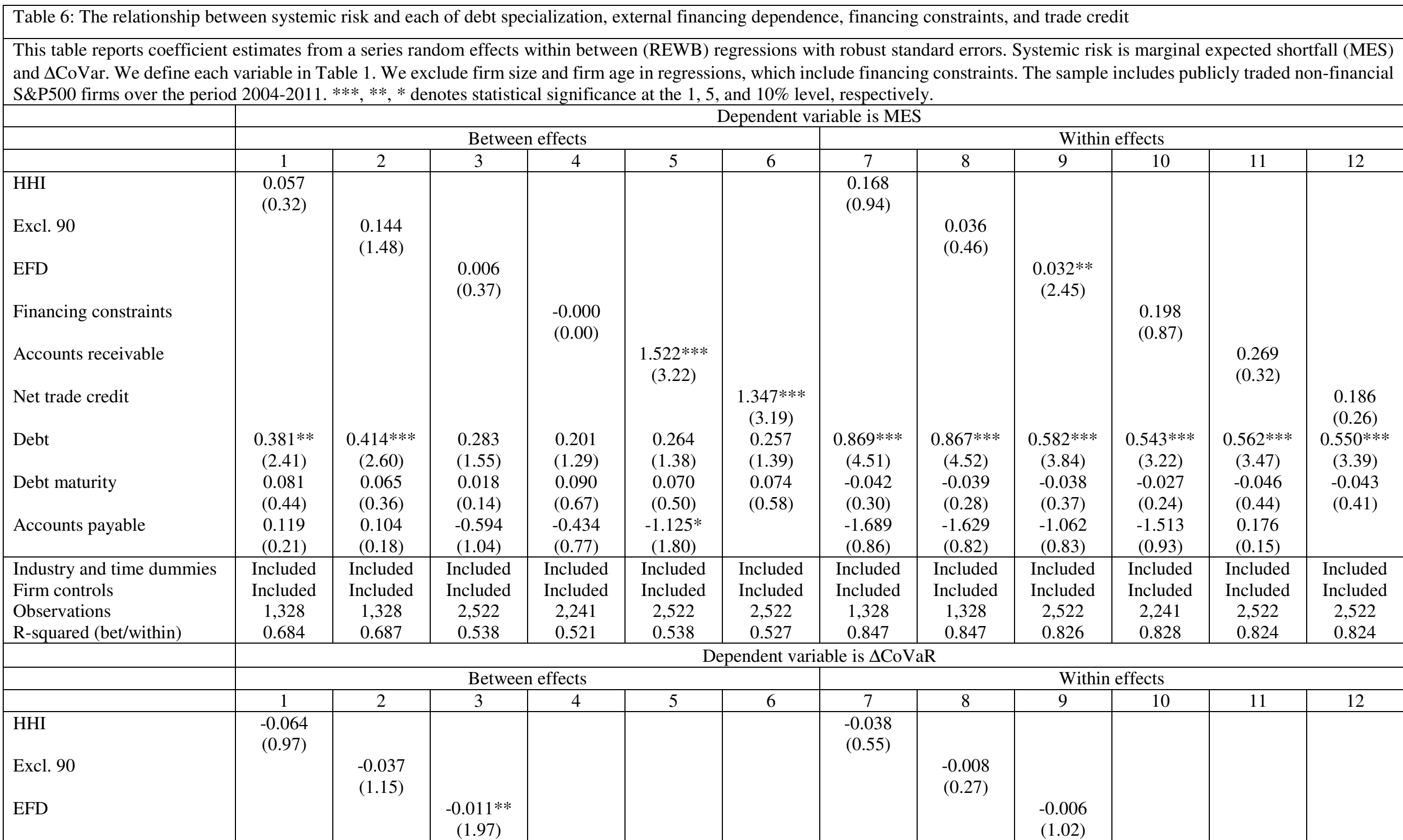




\begin{tabular}{|c|c|c|c|c|c|c|c|c|c|c|c|c|}
\hline \multicolumn{13}{|c|}{ 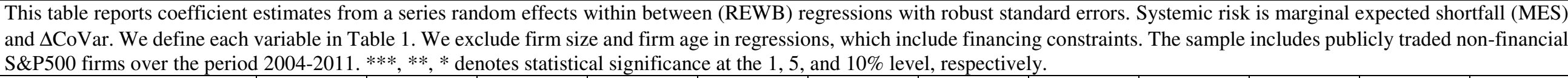 } \\
\hline Financing constraints & & & & $\begin{array}{c}-0.035 * * * \\
(2.64)\end{array}$ & & & & & & $\begin{array}{l}-0.063 \\
(0.97)\end{array}$ & & \\
\hline Accounts receivable & & & & & $\begin{array}{c}0.603 * * * \\
(3.68)\end{array}$ & & & & & & $\begin{array}{l}0.074 \\
(0.22)\end{array}$ & \\
\hline Net trade credit & & & & & & $\begin{array}{c}0.563 * * * \\
(4.22)\end{array}$ & & & & & & $\begin{array}{l}-0.065 \\
(0.20)\end{array}$ \\
\hline Debt & 0.019 & 0.021 & $-0.055^{*}$ & $-0.059 *$ & $-0.057 *$ & $-0.059 *$ & -0.026 & -0.026 & 0.018 & 0.025 & 0.013 & 0.011 \\
\hline & $(0.41)$ & $(0.48)$ & $(1.74)$ & $(1.81)$ & $(1.82)$ & $(1.92)$ & $(0.53)$ & $(0.53)$ & $(0.38)$ & $(0.50)$ & $(0.28)$ & $(0.25)$ \\
\hline Debt maturity & 0.021 & 0.017 & 0.024 & -0.001 & 0.027 & 0.029 & -0.098 & -0.101 & $-0.077 *$ & $-0.078 *$ & $-0.072 *$ & -0.068 \\
\hline & $(0.28)$ & $(0.21)$ & $(0.56)$ & $(0.01)$ & $(0.63)$ & $(0.66)$ & $(1.46)$ & $(1.50)$ & $(1.85)$ & $(1.84)$ & $(1.73)$ & $(1.64)$ \\
\hline Accounts payable & $\begin{array}{c}-0.401 * \\
(1.65)\end{array}$ & $\begin{array}{l}-0.391 \\
(1.60)\end{array}$ & $\begin{array}{c}-0.510 * * * \\
(2.89)\end{array}$ & $\begin{array}{c}-0.326^{*} \\
(1.79)\end{array}$ & $\begin{array}{c}-0.506 * * * \\
(2.81)\end{array}$ & & $\begin{array}{c}1.524 * * \\
(2.46)\end{array}$ & $\begin{array}{c}1.493 * * \\
(2.42)\end{array}$ & $\begin{array}{c}0.849 * * \\
(2.12)\end{array}$ & $\begin{array}{c}0.946^{* *} \\
(2.09)\end{array}$ & $\begin{array}{l}0.372 \\
(0.80)\end{array}$ & \\
\hline Industry and time dummies & Included & Included & Included & Included & Included & Included & Included & Included & Included & Included & Included & Included \\
\hline Firm controls & Included & Included & Included & Included & Included & Included & Included & Included & Included & Included & Included & Included \\
\hline Observations & 1,328 & 1,328 & 2,522 & 2,241 & 2,522 & 2,522 & 1,328 & 1,328 & 2,522 & 2,241 & 2,522 & 2,522 \\
\hline R-squared (bet/within) & 0.514 & 0.462 & 0.434 & 0.401 & 0.422 & 0.421 & 0.702 & 0.462 & 0.714 & 0.713 & 0.713 & 0.713 \\
\hline
\end{tabular}




\begin{tabular}{|c|c|c|}
\hline \multicolumn{3}{|c|}{$\begin{array}{l}\text { This table reports coefficient estimates from a series random effects within between (REWB) regressions with robust standard } \\
\text { errors. Systemic risk is marginal expected shortfall (MES) and } \Delta \text { CoVar. We define each variable in Table } 1 \text {. Large firm is an } \\
\text { indicator variable which is } 1 \text { if the firm size ranks in the top tercile of the size distribution. The sample includes publicly } \\
\text { traded non-financial S\&P500 firms over the period } 2004-2011 . * * *, * * * \text { denotes statistical significance at the } 1,5 \text {, and } 10 \% \\
\text { level, respectively. }\end{array}$} \\
\hline & \multicolumn{2}{|c|}{ Dependent variable is MES } \\
\hline & Between effects & Within effects \\
\hline Large firm indicator & $\begin{array}{c}0.138 \\
(0.80)\end{array}$ & $\begin{array}{l}0.294 \\
(1.25)\end{array}$ \\
\hline Debt & $\begin{array}{c}0.547 * * * \\
(3.79)\end{array}$ & $\begin{array}{c}0.662 * * * \\
(3.96)\end{array}$ \\
\hline Accounts receivable & $\begin{array}{c}1.722 * * * \\
(3.19)\end{array}$ & $\begin{array}{l}0.719 \\
(0.81)\end{array}$ \\
\hline Accounts payable & $\begin{array}{r}-0.771 \\
(1.25)\end{array}$ & $\begin{array}{l}-0.229 \\
(0.20)\end{array}$ \\
\hline Debt $*$ large firm indicator & $\begin{array}{c}-0.410^{*} \\
(1.85)\end{array}$ & $\begin{array}{c}-0.532 * * \\
(2.02)\end{array}$ \\
\hline Accounts receivable $*$ large firm indicator & $\begin{array}{l}-1.144 \\
(1.12)\end{array}$ & $\begin{array}{c}-3.656 * * \\
(2.40)\end{array}$ \\
\hline Accounts payable $*$ large firm indicator & $\begin{array}{l}0.030 \\
(0.03) \\
\end{array}$ & $\begin{array}{c}3.276 * * \\
(2.53)\end{array}$ \\
\hline Time dummies & Yes & Yes \\
\hline Industry dummies & Yes & No \\
\hline Controls & Yes & Yes \\
\hline Observations & 2,522 & 2,522 \\
\hline \multirow[t]{3}{*}{ R-squared (within/between) } & 0.576 & 0.826 \\
\hline & \multicolumn{2}{|c|}{ Dependent variable is $\Delta \mathrm{CoVaR}$} \\
\hline & Between effects & Within effects \\
\hline Large firm indicator & $\begin{array}{l}0.069 \\
(1.30)\end{array}$ & $\begin{array}{l}0.068 \\
(0.78)\end{array}$ \\
\hline Debt & $\begin{array}{l}-0.026 \\
(0.59)\end{array}$ & $\begin{array}{l}0.004 \\
(0.09)\end{array}$ \\
\hline Accounts receivable & $\begin{array}{c}0.538 * * * \\
(3.24)\end{array}$ & $\begin{array}{l}0.198 \\
(0.58)\end{array}$ \\
\hline Accounts payable & $\begin{array}{c}-0.538 * * * \\
(2.81)\end{array}$ & $\begin{array}{l}0.270 \\
(0.60)\end{array}$ \\
\hline Debt $*$ large firm indicator & $\begin{array}{l}0.009 \\
(0.13)\end{array}$ & $\begin{array}{l}0.014 \\
(0.23)\end{array}$ \\
\hline Accounts receivable $*$ large firm indicator & $\begin{array}{l}-0.100 \\
(0.32)\end{array}$ & $\begin{array}{c}-1.319 * * \\
(2.31)\end{array}$ \\
\hline Accounts payable $*$ large firm indicator & $\begin{array}{l}0.149 \\
(0.46) \\
\end{array}$ & $\begin{array}{c}1.424 * * * \\
(3.11) \\
\end{array}$ \\
\hline $\begin{array}{l}\text { Time dummies } \\
\text { Industry dummies } \\
\text { Firm controls } \\
\text { Observations } \\
\text { R-squared (within/between) }\end{array}$ & $\begin{array}{l}\text { Included } \\
\text { Included } \\
\text { Included } \\
2,522 \\
0.409 \\
\end{array}$ & $\begin{array}{l}\text { Included } \\
\text { Excluded } \\
\text { Included } \\
2,522 \\
0.714 \\
\end{array}$ \\
\hline
\end{tabular}




\begin{tabular}{|c|c|c|c|c|}
\hline \multicolumn{5}{|c|}{ Table 8: The influence of lifecycle on MES and $\Delta$ CoVaR } \\
\hline \multicolumn{5}{|c|}{$\begin{array}{l}\text { This table reports coefficient estimates from a series of firm fixed effects (within effects) and between regressions. } \\
\text { Systemic risk is marginal expected shortfall (MES) and } \Delta \text { CoVar. The sample includes publicly traded non-financial } \\
\text { S\&P500 firms over the period } 2004-2011 \text {. We report estimated coefficients for lifecycle stage only. } * * *, * *, * \text { denotes } \\
\text { statistical significance at the } 1,5 \text {, and } 10 \% \text { level, respectively }\end{array}$} \\
\hline & \multicolumn{2}{|c|}{ Dependent variable is MES } & \multicolumn{2}{|c|}{ Dependent variable is $\Delta \mathrm{CoVaR}$} \\
\hline & Between effects & Within effects & Between effects & Within effects \\
\hline & 1 & 2 & 3 & 4 \\
\hline Growth-stage & $\begin{array}{c}-0.454 * * \\
(1.98)\end{array}$ & $\begin{array}{c}-0.269 * * \\
(2.22)\end{array}$ & $\begin{array}{l}-0.041 \\
(0.58)\end{array}$ & $\begin{array}{l}0.043 \\
(0.91)\end{array}$ \\
\hline Mature-stage & $\begin{array}{c}-0.968 * * * * \\
(4.80)\end{array}$ & $\begin{array}{c}-0.349 * * * \\
(2.82)\end{array}$ & $\begin{array}{l}0.081 \\
(1.30)\end{array}$ & $\begin{array}{l}0.041 \\
(0.83)\end{array}$ \\
\hline Shake-out/decline-stage & $\begin{array}{c}-0.578 * * * \\
(2.68)\end{array}$ & $\begin{array}{c}-0.209 * \\
(1.77)\end{array}$ & $\begin{array}{l}-0.086 \\
(1.27)\end{array}$ & $\begin{array}{l}0.012 \\
(0.27)\end{array}$ \\
\hline \multirow{6}{*}{$\begin{array}{l}\text { Industry dummies } \\
\text { Time dummies } \\
\text { Firm controls } \\
\text { Observations } \\
\text { R-squared (between/within) }\end{array}$} & \multirow{3}{*}{\multicolumn{2}{|c|}{$\begin{array}{l}\text { Included } \\
\text { Included } \\
\text { Included }\end{array}$}} & \\
\hline & & & Inc & \\
\hline & & & Inc & \\
\hline & & \multicolumn{2}{|c|}{2,529} \\
\hline & 0.571 & 0.825 & 0.411 & \\
\hline & \multicolumn{4}{|c|}{ Tests for differences across lifecycle stages } \\
\hline $\begin{array}{l}\text { Growth-stage vs. mature-stage } \\
\text { Growth-stage vs. shake-out/decline } \\
\text { Mature-stage vs. shake-out/decline }\end{array}$ & **** & $* * *$ & $* *$ & \\
\hline
\end{tabular}




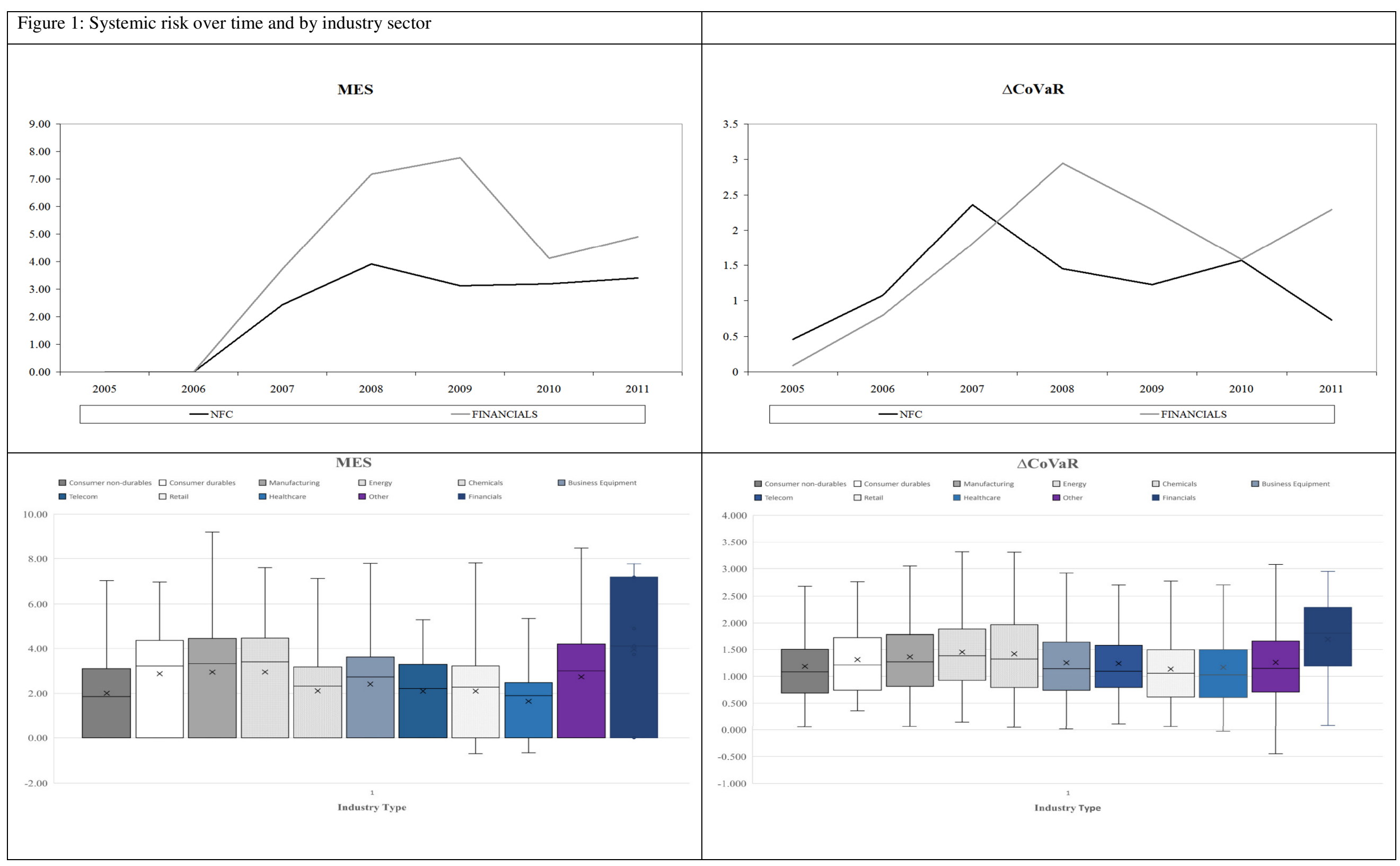




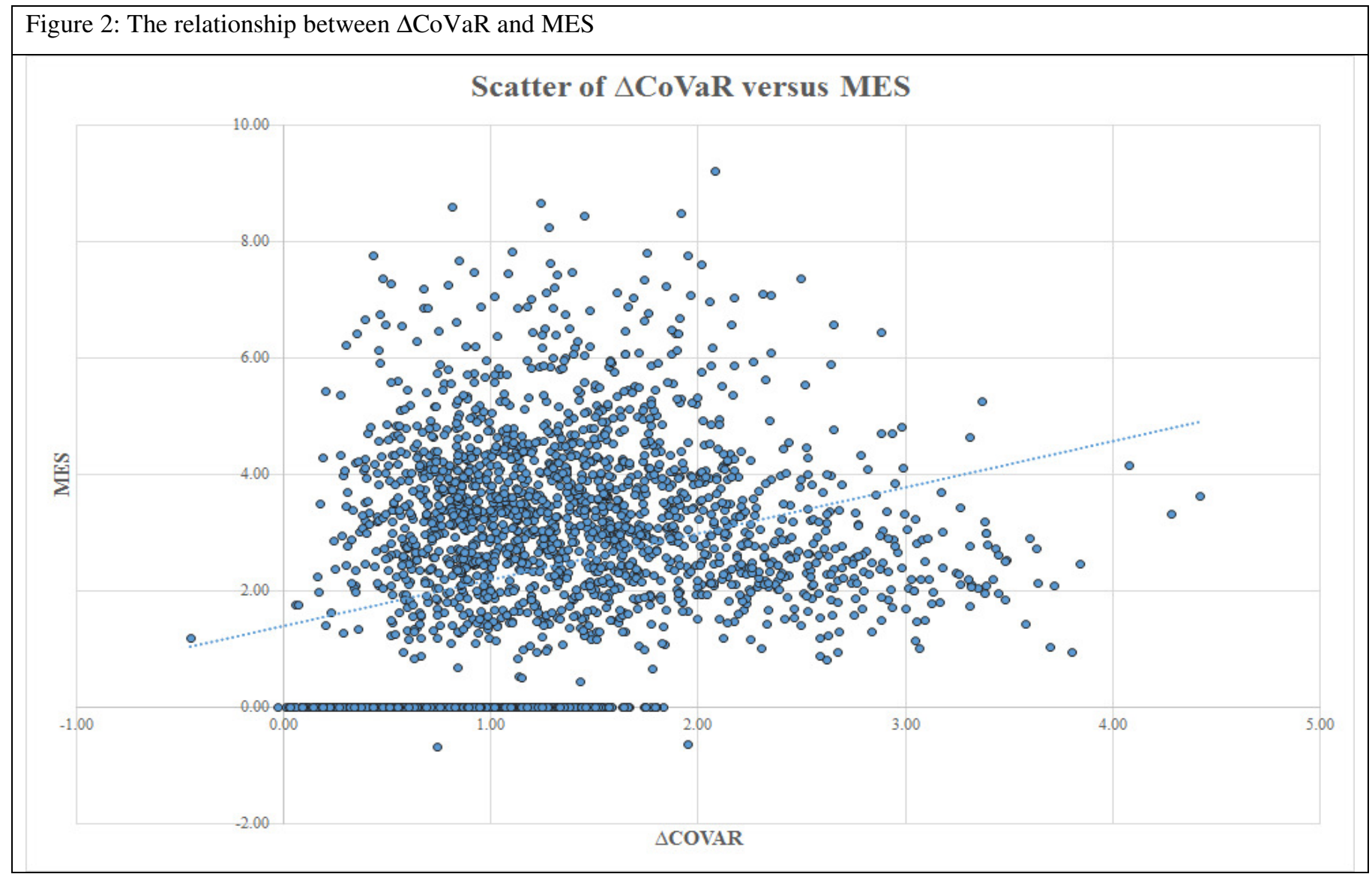

